OPEN ACCESS

Edited by:

Lora A. Richards, University of Nevada, Reno,

United States

Reviewed by:

Andrea Sciarretta,

University of Molise, Italy

Stephen Rogers,

University of Cambridge,

United Kingdom

*Correspondence:

Marion Le Gall

marionlegall314@gmail.com

Specialty section: This article was submitted to

Population and Evolutionary

Dynamics,

a section of the journal

Frontiers in Ecology and Evolution

Received: 02 March 2019 Accepted: 24 June 2019

Published: 23 July 2019

Citation:

Le Gall M, Overson R and Cease A (2019) A Global Review on Locusts

(Orthoptera: Acrididae) and Their Interactions With Livestock Grazing

Practices. Front. Ecol. Evol. 7:263.

doi: 10.3389/fevo.2019.00263

\section{A Global Review on Locusts (Orthoptera: Acrididae) and Their Interactions With Livestock Grazing Practices}

\author{
Marion Le Gall ${ }^{1 *}$, Rick Overson ${ }^{1}$ and Arianne Cease ${ }^{1,2}$ \\ ${ }^{1}$ School of Sustainability, Arizona State University, Tempe, AZ, United States, ${ }^{2}$ School of Life Sciences, Arizona State \\ University, Tempe, AZ, United States
}

Connections between locusts and people date back millennia and locusts remain a major food security challenge today throughout the world. Locust biology is often linked to abiotic conditions like temperature and/or precipitation, fueling the perception that aside from active control, humans are not key players in the interaction locusts have with their environment. However, several studies have shown that land management practices like grazing heavily influences locust-human linkages. In this review we synthesize published research and reports on connections between locust outbreaks and ranching. For this, we conducted an extensive literature search using Google Scholar on the 19 species of grasshoppers that are currently considered to be locusts or non-model locusts. Species were sorted according to their feeding guilds: (1) forb- and/or tree-feeding locusts; (2) mix-feeding locusts (grasses, forbs, and/or trees); (3) grass-feeding locusts. We review their pest status, ecology, and relationship with grazing. We then discuss the overall data and draw general patterns on how locusts and locust control affect livestock grazing through various mechanisms (competition, nutritional preferences, pesticide use, nutrient cycling). We draw attention to "telecoupling" a process in which land management practices like grazing have ecological feedbacks on locust populations, which in turn affects food security in distant regions due to the migratory capacity of locusts. Finally, we present new perspectives for sustainable management practices that integrate understanding of land management.

Keywords: grasslands, plant-insect interactions, locust phase change, land use and land cover change, drylands, nutrients, grazing

\section{INTRODUCTION}

Connections between locusts and people date back millennia and remain a major food security challenge throughout the world today. For instance, in Senegal, West Africa, locust outbreaks are second only to drought in damaging agricultural productivity (D'Alessandro et al., 2015). The impressive capacity of locust swarms to rapidly move long distances and descend on communities unexpectedly has shrouded their source in mystery. Perhaps for this reason, locusts have often been viewed as a divine punishment or curse; both the Bible and the Qur'an describe locusts as one of the devastating plagues of Egypt (El-Mallakh and El-Mallakh, 1994). 
The unpredictability and overwhelming nature of these outbreaks has also likely contributed to the perception that, outside of active treatment of outbreaks, people are passive recipients of swarms. However, increasing evidence suggests that human decisions about how we manage our land influence locust population dynamics (Cease et al., 2015). For example, in Inner Mongolia, China, heavy livestock grazing promotes Mongolian locust, Oedaleus asiaticus, outbreaks by lowering plant nitrogen content (Cease, 2012). Many other locust species also originate in areas used for livestock grazing. Yet, despite the known impacts of grazing on rangeland grasshoppers (Branson et al., 2006) and our longstanding connection with locusts, the potential to influence locust populations through land management practices has received relatively little attention. Here, we discuss how locust behavioral and migratory plasticity can lead to unique humanacridid linkages, outline the pest status, ecology, and interactions with grazing for all locusts, consider similarities and differences among species in various grazing systems, and highlight potential areas for further research.

At low densities, locusts, and grasshoppers are critical to grassland ecosystem functioning (Branson et al., 2006). They cycle nutrients, shape plant community structure, and are an important food source for many animals including spiders and birds (Wiens, 1973; Joern, 1986; Belovsky and Slade, 2000; Oedekoven and Joern, 2000; Sokol-Hessner and Schmitz, 2002; Schmitz, 2008). Humans also rear and consume locusts (Stoops et al., 2016; Osimani et al., 2017); they are the second most commonly eaten insect after crickets (Mignon, 2002; Osimani et al., 2017). At high densities, however, they compete with livestock for forage. In this scenario, locusts become highly problematic. Of the roughly 6,800 known acridid grasshopper species (Cigliano et al., 2017), 19 are currently considered locusts (Cullen et al., 2017). Locusts are grasshoppers that, when exposed to specific environmental cues, develop into either gregarious and swarming or solitarious phenotypes (Pener, 1991; Cullen et al., 2017). These phenotypes differ in behavior, morphology, and physiology; however, their component traits can be decoupled, and vary among species. Behavior can change within hours for some species but other traits, such as morphology, can take several generations to fully shift. This plasticity, termed locust phase polyphenism (Pener, 1991; Pener and Simpson, 2009), creates unique challenges. Gregarious locusts that originate in one region can migrate en masse hundreds of kilometers in a single night and plagues can span continents. For instance the desert locust, Schistocerca gregaria, can potentially affects 60 countries (Popov et al., 1991), and a single swarm can cover 1,200 $\mathrm{km}^{2}$ (Mohamed Shaluf, 2007). Successful management of locust upsurges requires the infrastructure both for robust monitoring throughout a locust's range to aid in early detection and for rapid and targeted treatment of nymphal bands. Effective management strategies thus often require international cooperation and a strong consideration of scale (Lockwood et al., 2001; Toleubayev et al., 2007).

When in the gregarious phase, locusts group together and become more polyphagous. Numerous anecdotal reports suggest that not only will gregarious locusts eat more plant species, but also plants belonging to different families than the ones they typically feed on when in the solitarious phase (COPR, 1982). Solitarious desert locusts, S. gregaria, avoid eating a plant species containing the alkaloid hyoscyamine but gregarious locusts will actively consume it, likely to gain gut-content mediated toxicity and avoid predation (Despland and Simpson, 2005a). Additionally, in the laboratory, gregarious locusts are less discerning when faced with artificial diets with nutrient imbalances as compared to solitarious locusts (Simpson et al., 2002). This expanded palate may be due to several reasons. On one hand, migrating individuals may encounter increased food diversity and this breadth may allow gregarious individuals to redress nutrient imbalances (Clark et al., 2013). On the other hand, groups of gregarious locusts may cross vast areas with no food and a narrower host plant breadth may mean starvation. This diet expansion, in combination with aggregation, likely heightens agricultural impacts. Indeed, locusts can cause 80$100 \%$ crop losses across affected areas (Brader et al., 2006).

Locust impacts on people are well-documented, but humans also influence locust population dynamics and distributions directly through control and indirectly through land use/land cover change; however, the latter has not been reviewed and summarized. For instance, due to targeted treatment in breeding zones, the red locust, Nomadacris septemfasciata (Serville, 1838), has had fewer outbreaks since the 19291944 plague (COPR, 1982; Thindwa, 1999; FAO, News Article: Red Locust disaster in Eastern Africa prevented, 2009. The impacts of the Moroccan locust, Dociostaurus maroccanus (Thunberg, 1815), also seem to be diminishing, most likely because its habitat has been replaced by croplands (although there are notable local exceptions that we will discuss below) (Latchininsky, 1998). On the other hand, land use change may increase the pest status of other species. For example, early swarms of the Australian plague locust, Chortoicetes terminifera, in the late 1800's may have been promoted by the introduction of European livestock and agriculture to Australia (Deveson, 2012). Therefore, understanding the grasslandlivestock-locust system will be an important contribution for solving pressing issues of food security and will provide an exploratory framework for revealing the pathways that connect human and ecological systems over large spatial distances (Cease et al., 2015).

\section{LITERATURE REVIEW}

To synthesize published research and reports on connections between locust outbreaks and ranching we carried out a literature search using Google Scholar. We searched for the binomial taxon names in quotations. Based on the raw count of hits from each binomial search we separated species into two groups: those with $<1,000$ hits (subset 1) and those with $>1,000$ hits (subset 2 ). For subset 1 , all article and report titles were viewed, and irrelevant articles were discarded. For the remaining articles in subset 1 , abstracts were individually reviewed. For species in subset 2 , due to the volume of articles initially queried, we further filtered articles by forcing them to contain either the word "grazing" or "livestock" and subsequently followed the same 
procedure as for subset 1 . Additionally, all pertinent references from COPR (1982) were reviewed. The seminal 1982 Locust and Grasshopper Agricultural Manual provides an excellent overview of the ecology and pest status of these (and many other) species. In this paper, there is some necessary overlap, but we focus on papers published after 1982 where possible and refer readers to the manual for reviews of older references. Results are presented by feeding guild (forb-and/or tree-feeding locusts; mix -feeding locusts; grass-feeding locusts), and taxonomic category. A third of the subfamilies in Acrididae have been found to be paraphyletic and to form four major clades (Clade A, B, C, and D) (Song et al., 2018). We thus included information on their subfamily and clades.

\section{FORB-AND/OR TREE-FEEDING LOCUSTS}

These forb or tree specialists are likely not strong competitors with livestock grazing on grasses, but they may be if livestock are limited to or prefer shrubs and trees (e.g., camels). Additionally, grazing areas may be preferable to these locusts, relative to cereal crop fields, presumably due to increased diversity of forbs and trees.

\section{Subfamily Calliptaminae-Clade D Calliptamus italicus (Linnaeus, 1758) \\ The Italian locust, or stout-bodied grasshopper}

Pest status. This species has been reported as a pest since medieval times and "raging" outbreaks remain common to date (Stolyarov, 2000). In the Siberian steppes its density sometimes exceeded 2000 individuals $\mathrm{m}^{-2}$. Economically important crops that are attacked include wheat, sunflowers, beans, and many more crop species (COPR, 1982).

Habitat and ecology. This locust can be found from the eastern Mediterranean region through the Siberian steppes to arid regions of northwestern China, and, in Europe, as far north as Germany (Louveaux et al., 1988; Sergeev and Van'kova, 2008). It inhabits primarily dry habitats including semi-desert steppes, rocky slopes, dry glades and pine forest edges, and shrubby terrain. It is also common in agrolandscapes (Sergeev and Van'kova, 2008) and degraded habitats (Louveaux et al., 1988). The Italian locust spends most of its time on the ground surface and is rarely found climbing on grass and forbs (Batáry et al., 2007). This species does not tolerate high humidity and eggs must be laid in soil containing $<5 \%$ moisture (Louveaux et al., 1988). It has one generation per year. Eggs are laid during the summer and undergo diapause during the winter. Outbreaks are associated with hot and dry springs and summers (Stolyarov, 2000) and females avoid laying eggs near shrubs and trees because of their cooling effect on soil (Urech, 2003). In some countries, like China, its range is likely to expand with climate change (Qin et al., 2012). The Italian locust differs from some other locust species by having no color distinction between the different phases (Sergeev and Van'kova, 2008). To distinguish between phases, researchers rely on morphometric features: body size and the ratio of forewing length to hind femur length (gregarious individuals are bigger) (Sergeev and Van'kova, 2008).
Grazing interactions. Despite feeding primarily on forbs, Italian locust populations are sometimes associated with grazing fields and pastures and will attack forage including fodder grasses as well as alfalfa (COPR, 1982). In steppe habitats, this locust likely competes to some extent with cattle; however, the primary economic impact arises when it moves from grazing or natural areas to cropland. In Eastern Kazakhstan, even between the outbreaks, the locust density can be very high (up to 20-26 individuals $\mathrm{m}^{-2}$ ), and this is especially true for fallow lands, overgrazed pastures, and belts of perennial grasses within croprotation fields. Interestingly this locust rarely inhabits fallow lands dominated by wheat grass (Sergeev and Van'kova, 2008), but has been described as a pest of wheat (Wilps et al., 2002). Intensive tillage of steppes near the Irtysh River in the late 1950searly 1960s promoted larger Italian locust populations, which then spilled into fields with perennial grasses and grain crops, ecotones, and pastures (Sergeev and Van'kova, 2008), but the mechanism of this interactions is unknown.

\section{Subfamily Cyrtacanthacridinae-Clade D Anacridium melanorhodon (Walker, 1870)}

The Sahelian tree locust

Pest status. This species is primarily a tree pest (e.g., gum arabic, apple trees, citrus trees, palm date, olive trees, mango trees), but young nymphs will feed on grass and adults will feed on crops including bulrush millet, sorghum, maize, rice, cassava, cotton during the winter (dry) season and when swarming (COPR, 1982). Of greatest economic importance is its impact on gum arabic production. Gum arabic is one of the main crops produced in the traditional rain-fed agricultural sector of Sudan and South Sudan and is especially important for the semi-nomadic people in the Savannah belt of the region (Haroon et al., 2011). It is a non-timber forest product harvested from gum arabic tree (mainly Acacia senegal var. senegal). Gum arabic provides on average $12 \%$ of the gross domestic product of the country and accounts for about $15-10 \%$ of the income of the gum producers and other farmers in the gum belt across the Sudan. A study conducted in North Kordofan State in Sudan showed that gum arabic crop yield was more than halved by locusts (going from 273.9 to $93.8 \mathrm{~kg} / \mathrm{ha}$ ) and financial benefits plummeted from 292.6 Sudanese Pound (SDG) per hectare to losses of -21.2. SDG per hectare (Elamin et al., 2008). In addition, tree locust outbreaks can delay tree tapping from October to January/February because of defoliation.

Habitat and ecology. This locust is well-adapted to arid habitats and drought. It can resorb water from frass under hot and dry conditions and feeds almost exclusively at night (Abushama, 1970; COPR, 1982). It is physiologically adapted to feed on trees, containing phenols such as tannic and gallic acids and these compounds actually stimulate feeding. Typically, phenols are harmful to herbivores because they bind to leaf proteins and inhibit protein digestion post-consumption. To limit this effect, locusts use these ingested compounds as a source of phenolics in tanned cuticle, rather than obtaining them from the aromatic amino acids tyrosine and phenylalanine as most insects do (Evans and Bell, 1979; Bernays and Woodhead, 1982; Bernays et al., 
1983). The aptly named Sahelian tree locust is distributed in the Sahelian zone from Cape Verde to Ethiopia, as well as parts of the Middle East (COPR, 1982).

Grazing interactions. Because it feeds on trees, this locust is probably not an important competitor for grass grazers, however it can compete with domestic cattle and camels when feeding on wild trees and shrubs (e.g., Boscia senegalensis) (COPR, 1982). In areas that are overstocked, the Sahelian tree locust can exacerbate the impact of livestock on shrubs and trees, with subsequent impacts on soil quality. In Sahelian sylvopastoral systems, woody vegetation can limit soil degradation by reducing top soil erosion (Breman and Kessler, 1997). On the other hand, the Sahelian tree locust may contribute significantly to nutrient cycling in silvopastoral systems. For example, a study quantified the nitrogen deposited during a locust outbreak in an Acacia tortilis woodland in Oman (Robinson, 2001). The average fecal deposition was $65.28 \mathrm{~g} \mathrm{~m}^{-2}$. The mean fecal crude protein and $\mathrm{N}$ were respectively, 20.14 and $3.22 \mathrm{~g}$ per $100 \mathrm{~g}$ ash-free dry weight, or roughly $1.1 \mathrm{~kg}$ of fecal $\mathrm{N}$ per ha. For comparison, this single contribution by locusts equals about one-third of the total standing crop of detrital $\mathrm{N}$ under perennial vegetation in a hectare of the Mohave Desert of North America. These calculations, combined with the seasonal prevalence and diversity of grasshoppers in dry areas, suggests they are likely broadly important for nutrient cycling in arid systems.

\section{MIX-FEEDING LOCUSTS (GRASSES, FORBS, AND/OR TREES)}

Mix-feeding locusts tend to be highly polyphagous, eating broadly from many plant families. This adaptation allows them to persist in and migrate through many landscape types. It also makes plagues a significant threat to livestock forage and pastures, as well as a broad array of crops. Several of these species prefer overgrazed, or otherwise disturbed, habitat, potentially due to increased bare soil for laying eggs and thermoregulating.

\section{Subfamily Cyrtacanthacridinae-Clade D Schistocerca cancellata (Serville, 1838) \\ South American locust}

Pest status. The first report of damage from S. cancellata was on cassava in 1538 in Buenos Aires (Gastón, 1969), and since that time, the list of damaged plants has grown to virtually every cultivated plant in Argentina including soybeans, sorghum, maize, peanut, and citrus, as well as pasture grass. From the 1800 's to 1954 , plagues increased in frequency and size causing millions of tons of crop and pasture losses in Argentina alone, and historically spanned from Argentina, Bolivia, Paraguay, Uruguay, Chile, and Brazil (COPR, 1982). Starting in the 1960's, consistent monitoring and pesticide application (including DDT) is thought to have led to successful control for the next six decades, with only three small outbreaks in 1961, 1989, and 2010 (Waloff and Pedgley, 1986; Medina et al., 2017). However, in 2015 a large upsurge began, likely promoted by elevated winter temperatures and rainfall (Medina et al., 2017). The outbreak has persisted to the present (March 2019), expanding from a small region in NE Argentina into much of the rest of country, as well as into neighboring Bolivia and Paraguay. Continued monitoring and pesticide application is underway in the tri-country response (Medina et al., 2017).

Habitat and ecology. This highly polyphagous locust prefers desert or semidesert areas and likely persists mainly in a central permanent zone $(\sim 600 \times 200 \mathrm{~km})$ within Argentina (Köhler, 1962) that receives $250-400 \mathrm{~mm}$ of annual precipitation. Breeding populations are hypothesized to persist in this zone due to sufficient habitat heterogeneity, which acts as a refuge even during unfavorable times (COPR, 1982; Waloff and Pedgley, 1986). However, solitarious individuals at low density have been found consistently across Argentina as well as in a small region in Chile (M. Pocco \& H. Song, pers. comm.). Work by Hunter and Cosenzo (1990) demonstrated a link between the occurrence and persistence of outbreaks in South America and the timing of rainfall particularly in the states of Catamarca and La Rioja. With a longer developmental time than S. gregaria (Pedgley, 1981), S. cancellata relies on rainfall between late spring and late summer (November and March, respectively) and generally spends the dry season (April-October) as nymphs, in a type of reproductive diapause (Barrera and Turk, 1983). However, Hunter and Cosenzo demonstrated that rainfall in the recession zone during winter months followed by a wet consecutive spring and summer, allows three generations per year and fuels dramatic population growth. This sequence is highly predictive of outbreaks from 1897 to 1954 . Once upsurges were initiated with a three-generation year, they generally grew to maximum size over the following 2 years, and then diminished gradually over 8-15 years due to the effects of attenuating dry years that allowed for only a single generation in Catamarca and La Rioja.

Grazing interactions. The dominant vegetation of the permanent breeding zone is a wooded steppe of Prosopis and Larrea bushes and some areas are used for large-scale, low-density livestock grazing (pers. obs.); however, grazing impacts on the South American locust are unknown. Interestingly, recent experiments showed that gregarious marching bands of this species are carbohydrate (not protein) limited in the permanent zone, and even more so in its recent invasion area in southern Bolivia (Overson et al. unpublished data). These results suggest $S$. cancellata might prefer low nitrogen (low protein, high carbohydrate) plants, at least while migrating. Potentially, grazing practices that lower plant nitrogen content could promote South American locust outbreaks, similar to the Mongolian locust (Cease, 2012). However, despite their affinity for carbohydrates over protein (Overson et al. unpublished data), this species is remarkably polyphagous and has been recorded eating a variety of presumably high protein plants (e.g., Prosopis, soy, peanut). During upsurges, swarms expand throughout the larger species range resulting in widespread invasion into including both grazing and crop land. During the current (20152018) upsurge, damages were reported to natural pastures with only minor impact on crops in Argentina. In Bolivia, nymphal bands, and adults damaged soybeans, maize, sorghum, peanut, and citrus. In Paraguay, nymphs and adults were detected on natural pastures and shrublands (Medina et al., 2017). 


\section{Schistocerca gregaria flaviventris (Burmeister, 1838); Schistocerca gregaria gregaria (Forskål, 1775) Desert locust}

Taxonomic notes. The S. gregaria flaviventris subspecies is found in southern Africa, exists as solitarious phenotypes, and rarely undergoes phase change-outbreaks from 1934 to 1935 and 1948 being two limited exceptions (Chapuis et al., 2017). Therefore, our review focuses on S. g. gregaria, the phase-changing northern subspecies that forms massive swarms. This locust has been the focus of extensive life history and biology research (reviewed in COPR, 1982; Symmons and Cressman, 2001; Pener and Simpson, 2009; Cullen et al., 2017), including food selection and nutrient balancing (Maxwell-Darling, 1936; Chandra and Williams, 1983; Behmer et al., 2001).

Pest status. Desert locust swarms typically originate in desert regions mostly uninhabited by people across North Africa, the Middle East, and Southwest Asia. However, this species' expansive invasion zone is among the largest of any locust and includes many agricultural areas (Popov et al., 1991). S. gregaria has caused periodic devastation for millennia and was recorded as early as 2420 BC in Egyptian tombs (Nevo, 1996). This species remains a threat through modern times, although recent plagues persist for shorter time periods. For example, before 1963 , plagues in the 1900 s persisted $7-14+$ years (Waloff and Green, 1976; Symmons and Cressman, 2001); the four plagues that occurred between 1965-2006 each lasted <3 years (Magor et al., 2008). This decline is correlated with implementation of preventative desert locust control (Magor et al., 2008; Symmons, 2009). Nevertheless, desert locust outbreaks and plagues remain costly. The last major plague was 2003-2005, costing over $\$ 500$ million USD to control (Belayneh, 2005) and resulting in $80-100 \%$ crop losses in afflicted regions, predominantly SubSaharan Africa (Brader et al., 2006). These short-term devastating impacts on agriculture have long-term effects on livelihoods, including educational outcomes. A study based in Mali showed that children born during the 1987-1989 plague in villages hit by locusts were less likely to ever start school; the effect was greatest for young women (De Vreyer et al., 2014). Since 2005, and as of February 2019, no plagues have occurred, but there have been numerous localized outbreaks allowing formation of smaller swarms, including swarms originating from along the Red Sea in early 2019 (FAO Locust Watch: http://www.fao.org/ag/locusts). The desert locust eats a wide variety of crops and other plants, including a broad assortment vegetable and cereal crops, banana, citrus, groundnuts, fruit trees, coffee, and many others (reviewed in COPR, 1982). Due to its vast reach and significance to agriculture, this species is often considered the most dangerous migratory pest in the world (Steedman, 1990).

Habitat and ecology. The desert locust is well-adapted to live in a vast arid and unpredictable landscape. During recession years, S. gregaria live in a broad belt of arid and semi-arid habitat that spans from the western coast of Africa to northwest India and has an average annual of rainfall of roughly $0-400 \mathrm{~mm}$. The rainfall is sporadic, unpredictable, and can vary as much as $70 \%$ above or below average. Outbreaks can arise unpredictably from many areas within the expansive recession zone if the areas receive rain in sufficient amounts and timing to develop habitat suitable for locust growth (Cressman, 2016). S. gregaria is multivoltine, with up to three generations per season under favorable conditions. Typically, it takes several years for outbreaks to develop into a plague, but plagues can subside within 6 months (Roffey and Magor, 2003). Locusts can travel $150 \mathrm{~km}$ in a day and typically migrate between seasonal breeding areas (Pedgley, 1981). Heavy rains can allow for population buildup within the recession zone. As vegetation rescinds, locusts aggregate, which can lead to gregarization.

Schistocerca gregaria research has been foundational to our understanding of locust phase polyphenism. Tactile stimulation on the hind femur (Rogers et al., 2003) or a combination of visual and olfaction stimuli from conspecifics (Roessingh et al., 1998) will induce behavioral phase change. This behavioral shift from the solitarious to gregarious phase is modulated by a pulse of serotonin (Anstey et al., 2009), can take place in $4 \mathrm{~h}$, and involves an increase in activity and attraction to conspecifics (Rogers et al., 2014). There are several lines of evidence to suggest that this initial behavioral shift is an anti-predator strategy. S. gregaria (and several other, but not all, locust species) develop aposematic coloration when at high density and will accept foods containing the alkaloid hyoscyamine (Despland and Simpson, 2005a), which garners them "gut-content mediated toxicity" (Sword, 1999, 2001). At a small scale, clumped resources promote interactions and consequent gregarization (Bouaïchi, 1996; Collett et al., 1998; Despland and Simpson, 2000; Despland et al., 2000; Babah and Sword, 2004; Cisse et al., 2013, 2015), but this relationship may be the opposite at large, landscape-scales (Despland et al., 2004). In addition to resource distribution, food quality affects phase change. For example, S. gregaria given multiple options of imbalanced diets will switch more regularly among them to attain complementary nutrients, which increases the rate of contact with other locusts (Despland and Simpson 2000). The mechanisms and consequences of phase change are reviewed in depth in Cullen et al. (2017).

Grazing interactions. Gregarious swarms in the invasion zone have a much-expanded list of plants they will consume (COPR, 1982), leaving a broad range of crops and rangeland vulnerable. Abou-Ali and Belhaj (2008) explored the benefits and costs of locust control campaigns in Morocco, Sudan, and Eritrea from 1980 to 2000. The desert locust caused significant losses in crop and fodder, the latter decreasing livestock production. However, pesticides had negative effects on human, livestock, and environmental health. Considering these tradeoffs, as well as the cost of control, a contingent valuation method showed that, as an alternative to pesticides, farmers would be willing to pay an annual fee that would later be used to compensate affected farmers in the event of an invasion (Abou-Ali and Belhaj, 2008). For a comprehensive review on management strategies for $S$. gregaria to reduce damage to crops and livestock grazing areas, see Van Huis et al. (2007).

Field observations suggest that camel grazing accelerates gregarization, potentially by concentrating locusts onto ungrazed 
vegetation (Roffey and Popov, 1968). However, when in agricultural areas, S. gregaria tends to be more prevalent in cultivated areas, relative to grazing sites (Van Der Werf et al., 2005). Moreover, when in grazing areas, the desert locust may eat trees and shrubs and not be in direct competition with livestock (Wilps and Diop, 1997). This pattern might be explained by a preference for high nitrogen plants. S. gregaria grows faster and has higher survival rates when fed nitrogen-fertilized millet, in contrast to other locusts (Van Huis et al., 2008). The same study showed that $S$. gregaria is also more abundant in areas with lower grazing pressure and higher-nitrogen plants.

\section{Schistocerca interrita (Scudder, 1899) Peruvian locust}

Taxonomic notes. The regional common name for this species "langosta migratoria" confuses taxonomic identification as the name is applied to $S$. piceifrons peruviana as well (Duranton et al., 2006).

Pest status. Until 1983-84, this species was known only as a nonswarming grasshopper in Peru until an upsurge connected to El Niño and the resulting extreme rainfall in the Lambayeque Desert in northern Peru (Duranton et al., 2001). El Niño years drive a pattern where the Lambayeque Desert becomes a productive breeding ground leading to upsurges, a phenomenon attributed to the two most recent outbreaks in the area as well. A large outbreak which spread throughout the Lambayeque and Cajamarca provinces in 1998 led to a campaign of government monitoring and spraying driving an end to the upsurge by 2002 with control efforts costing an estimated $\$ 2,057,000$ USD (Morales R.S. pers. comm.). More recently, an anticipated outbreak due to El Niño occurred in 2017 with successful preventative treatment beginning in May via monitoring and spraying of focal areas totaling 7,769 hectares scattered throughout a much larger 320,000 hectare region (Morales R.S. pers. comm.).

Habitat and ecology. Schistocerca interrita is a mix-feeder that prefers dry wooded areas with sandy soils where plants in the genus Caparus and Angularis occur, as well as anthropogenically cleared areas (Duranton et al., 2006). Plants in the family Solanaceae such as Exodeconus prostatus as well as grasses are known food sources when solitarious individuals are at low densities (Morales R.S. pers. comm.). Nymphs are green at low density but develop black and yellow markings at high density. Basic ecology and population dynamics have not been well-studied (Song, 2011). Adults move seasonally to 2,800$3,300 \mathrm{~m}$ elevation tracking green vegetation during the dry season of winter. During the wetter summer, adults move to lower elevations $(500-1,000 \mathrm{~m})$ to mate and oviposit. The species is also possibly bivoltine, with a spring generation from eggs laid by seasonally descending adults at intermediate elevations around $1,800 \mathrm{~m}$, and a second generation born at lower elevations (Duranton et al., 2006). After birth, nymphs move to higher elevations gradually as they develop through five (or sometimes six) instars. During winter, adults diapause and later become reproductively capable around September and onward into summer.

Grazing interactions. The Peruvian locust is known to have an affinity for areas which have been anthropogenically cleared for grazing and for overgrazed areas and these are of focus during monitoring and treatment (Morales R.S. pers. comm.).

\section{Schistocerca piceifrons Peruviana (Lynch} Arribalzaga, 1903); Schistocerca piceifrons piceifrons (Walker, 1870)

\section{Central American locust}

Taxonomic notes. Research and management of S. piceifrons has been confounded by a history of misidentifications and nomenclatural changes. Originally, the species was described as Acridium patianum and subsequently described as two different species by F.L. Arribálzaga: S. peruviana and then S. urichi (Lynch Arribalzaga, 1903, 1918). The species has also often been confused with either $S$. gregaria or $S$. americana. It was incorrectly referred to as $S$. paranensis in the literature (a name originally applied to the gregarious form of S. cancellata). One invasion in Guyana in 1917 led to printed identifications of four different names (Harvey, 1983). As currently described, S. piceifrons has two subspecies: one from Mexico and parts of Central America (S. $p$. piceifrons) and the other from Peru, Ecuador, Colombia, Venezuela, Panama, and Trinidad and Tobago (S. p. peruviana) (Harvey, 1983; Barrientos Lozano et al., 1992).

Pest status. Schistocerca piceifrons piceifrons has been responsible for high levels of agricultural damage historically throughout southern Mexico and northern Costa Rica making it one of the most important pests in that region (Harvey, 1983; Barrientos Lozano et al., 1992; Cullen et al., 2017). S. piceifrons has a long history as a pest, and has even been implicated in the downfall of the Mayan civilization (Flores Granados, 2011). Upsurges of $S$. $p$. piceifrons were recorded as early as 1611 with an average of 3-5 plagues per century thereafter, affecting every country in Central America (COPR, 1982). Plagues during 192223 almost certainly originated from resident populations of $S$. piceifrons in Campeche and Yucatán but this was not recognized due to confusion about the solitarious and gregarious phases (Harvey, 1983). Three permanent breeding areas were detected historically for S. p. piceifrons in Central America (Harvey, 1983), including one in the Yucatan which has been under strong management focus recently as a site of continual gregarization and invasion source for a large zone in the region including Veracruz, San Luis Potosí, Tamaulipas and Tabasco (Cullen et al., 2017). To this day, S. p. piceifrons continues to be one of the most damaging insect pests in all Mexico and Central America. Intensive monitoring and pesticide treatments are implemented to stave off outbreaks virtually every year for this species in Mexico throughout an area of 64 municipalities in the states of Campeche, Chiapas, Hidalgo, Oaxaca, Quintana Roo, San Luis Potosí, Tabasco, Tamaulipas, Veracruz and Yucatán with major damage reported on corn, soy, beans, peanut, cotton sugar cane, coco, citrus, and others (SENASICA-D GSV, 2016). The 
subspecies S. piceifrons peruviana is currently of management concern in Peru and is regularly monitored and sprayed but has not had any major eruptions of significant economic importance since a large upsurge from 1945 to 1948 and is less economically significant than the sympatric S. interrita in Peru (Morales R.S. pers. comm.). In addition to low volume spraying focusing on nymphs, manual collecting of individuals are used in control of this species, as well as poisonous baits, especially in areas where livestock poisoning is a concern (Morales R.S. pers. comm.).

Habitat and ecology. This species is a generalist herbivore distributed from southern Mexico throughout Central America and northern South America where annual rainfall is between 100 and $250 \mathrm{~mm}$ and there is both a distinct dry winter and no cold season. Dry tropical woodland is believed to be the native habitat (Harvey, 1983) and it is not found in appreciable numbers in mature woodlands. Habitats that can support higher densities contain bare earth, food plants (which are composed of variable plant communities from site to site) (Bredo, 1963), and tall shrubs for shelter (Harvey, 1983). In Mexico, the species is bivoltine with generations in spring and fall. The spring generation is shorter in duration (Hernández-Zul et al., 2013) and the fall generation goes into diapause as adults (Song, 2011). Nymphs are green at birth and at low density, but at high density exhibit black markings on a peach background (Hunter-Jones, 1967). Unlike findings with S. gregaria (Ellis and Ashall, 1957), nymphs are able to move through high grass without losing cohesion, even traveling by climbing shrubs and leaping from one to the next (Harvey, 1983). Gregarious adults become bright yellow when sexually mature (Harvey, 1983). Similar to other locusts, behavior of adults can change post-molt depending on density of conspecifics so that gregarious vs. solitarious morphology and physiology can be decoupled (Harvey, 1983). Life history characteristics have been studied both in the laboratory (Hunter-Jones, 1967) and two locations in the field (Bredo, 1963). Most individuals have six nymphal instars but some males have only five. This species is a strong generalist feeding on: maize, wheat, rice, palms, citrus, sunflower, soybeans lentil, wax myrtle, potato, tobacco, banana, sugarcane, sorghum, and more (COPR, 1982; Cullen et al., 2017). S. p. piceifrons appears to use the patchily distributed shrub Pisonia aculeate for refuge, as the plant remains green yearround. This plant potentially drives aggregation by concentrating locust densities (Poot-Pech et al., 2016; Cullen et al., 2017). Research on the environmental drivers of locust density in the Yucatán peninsula demonstrated a correlation between locust density and the presence of the grass Panicum maximum, but no correlation with soil type (Poot-Pech et al., 2018).

Grazing interactions. Over the past 30 years, the state of Yucatán has experienced a dramatic increase in the conversion of forest to grassland driven by ranching and agriculture. A $47 \%$ increase in grassland from 1981 to 2014 has greatly expanded suitable habitat in the region for S. piceifrons as well as its capacity for gregarization and swarming, making the Yucatán of prime importance for managing locust swarms (Poot-Pech, 2016). Additionally, the ranching practice of burning dried grass annually to promote regrowth in the spring encourages aggregation and thus gregarization by locusts by creating patchworks of bare soil that are desirable for oviposition. Earlier observations of $S$. $p$. piceifrons found them commonly in disturbed forest, as well as extensive plantations of sisal (Yucatán) that are harvested on 7-year cycles and harbor locusts during regrowth cycles. In Campeche, hopper bands were observed by Harvey in 1981 in pastureland with regrowth of trees and cleared roadsides. In these instances, nymphs were always marching downwind and tended to accumulate in shrubby weeds when moving across bare ground, likely maintaining or heightening gregarization. Well-maintained crops and pasture are apparently not suitable habitat (COPR, 1982).

\section{Gomphocerinae - Clade B Dociostaurus maroccanus (Thunberg, 1815) Moroccan locust}

Pest status. This locust was likely one of the grasshopper species described in the bible due to its spectacular plagues. It is highly polyphagous and attacks cereal, but also, vegetables, forage, oil producing crops, fruit trees, date palms, and even conifers (Latchininsky, 1998). Crop damage from D. maroccanus has been reported in more than 25 countries, often requiring military help for control (Latchininsky, 1998). Interestingly, it appears that outbreaks are less frequent in recent years, probably because croplands are replacing locust habitat. However, in some portion of its range, overgrazing can make locust problems worst (Latchininsky, 1998).

Habitat and ecology. The Moroccan locust lives in dry, degraded areas, with bare patches of soil and fragmented vegetation cover (Latchininsky and Launois Luong, 1992). It can be found from the Atlantic islands (Madeira and Canary islands), throughout the Mediterranean zone, to Afghanistan and South Kazakhstan (Latchininsky and Launois Luong, 1992). This species feeds on over 150 plant species belonging to 33 families, including 50 different crop species (Latchininsky and Launois Luong, 1992). This is unusual for a grasshopper belonging to the Gomphocerinae sub-family, whose members are typically grass feeders. Its feeding habits are reflected in its biology: it has a higher number of sensilla relative to other Gomphocerinae and is more similar in this regard to mix-feeding species belonging to the Oedipodinae sub-family (Ghadraoui et al., 2002).

Grazing interactions. Dociostaurus maroccanus has significant interactions with livestock as a competitor because it attacks forage crops (COPR, 1982) and can be extremely abundant in overgrazed pastures. Overgrazing likely promotes outbreaks of this species because it leads to fragmented vegetation cover and bare soil, which is the ideal habitat for the Moroccan locust (Latchininsky, 1998). Indeed, this locust tends to colonize areas where the natural vegetation has been disturbed and is patchy. In Algeria, such areas are concentrated around human settlements, earning Moroccan locusts the name djerad-el-adami ("man's locust") (Pasquier, 1934). Similarly, locust penetration into previously uninhabited arid areas of the Middle East usually follows the paths of nomadic herders of cattle and sheep (Skaf, 1972). Overgrazing throughout the range of D. maroccanus has become increasingly common (Uvarov, 1977) due cropland 
expansion and subsequent reduction in available grasslands for livestock grazing.

\section{GRASS-FEEDING LOCUSTS}

Most locust species are grass-feeders (12 out of 19 species). Grass-feeders theoretically only feed on plants belonging to the family Poaceae. However, this designation is nuanced on two levels. Firstly, grasses belongs to the fifth-largest plant family with over 10,000 species and are very ubiquitous in their distribution (Gibson, 2009). Secondly, following gregarization locust hostplant range expands considerably (Despland, 2005) and every single species described below has been reported feeding on plants outside of the Poaceae family during outbreaks. Grassfeeders are thus typically present in grassland and pastures where they compete with livestock. They readily feed on Poaceae of economic interest like cereals or forage, but they can also cause serious damage to non-grass crops during outbreaks.

\section{Subfamily Cyrtacanthacridinae - Clade D Austracris guttulosa (Walker, 1870) (Synonyms: Nomadacris guttulosa) \\ Spur-throated locust}

Pest status. This locust is fairly common in southwestern Australia, but typically only forms swarms above $25^{\circ} \mathrm{S}$ latitude. It feeds on a wide range of crops with well-documented damage historically (COPR, 1982 and references therein), including sorghum, sunflowers, soybeans, millet, wheat, eucalyptus, banana, and citrus. Additionally, native trees (Eucalytpus, Acacia), shrubs (Dodonaea), and several grasses are consumed and allow the species to persist in marginal conditions (COPR, 1982). This species is of less economic importance than other Australian orthopteran pests and, as nymphs they are not considered economically viable to control unless in and around high-value crops. However, this species will cause economically relevant damage once a threshold of around 20 nymphs or 3 adults per $\mathrm{m}^{2}$ is reached (DPI, 2018).

Habitat and ecology. This large brown locust is a tropical dryland locust with a lifecycle adapted to a prolonged, dry winter and wet summer. Observation and mandible morphology suggests a preference for grass over dicotyledons (Bullen, 1968; COPR, 1982). The species is univoltine and survives the dry season as sexually immature adults with low feeding rates that overwinter in large clusters in trees (Jenkins, 1968; COPR, 1982). Sexually mature individuals engage in long distance migrations under the cover of darkness in spring and summer from Oct-Jan. During autumn and winter young adults engage in shorter migratory flights (DPI, 2018). Adult females lay eggs on summer nights between Dec-Jan on cracking clay soils (COPR, 1982). Grass plains with clay-rich soil in the North Territory and Queensland support high levels of breeding (Bullen, 1968). In one irrigated area in Western Australia oviposition was concentrated along banks and cleared areas adjacent to irrigation canals (Bullen, 1968). Anthropogenically cleared areas such as roadsides are also used as oviposition sites (COPR, 1982).
Grazing interactions. The first swarms recorded in New South Wales (NSW) were in 1973 , which was $8^{\circ}-10^{\circ}$ of latitude further south than its previously described breeding range (Casimir and Edge, 1979). That same summer, in March of 1974, swarms moved from sorghum fields in NSW into grazing country. Individual swarms throughout the grazing areas ranged in size from 200 to 800 ha where they roosted in and completely defoliated trees, in addition to eating pasture grass. One of three key factors implicated in the 1974 swarming event was the conversion of grazing land to cereal, oil-seed, and sorghum production in the preceding decade (Casimir and Edge, 1979). Nymphs and adults of this species are found abundantly in medium size forage grasses such as Chloris gayana which provide excellent shelter and food (COPR, 1982). Nymphs of this species often move into crops from nearby rangeland so effective management includes treating adjacent rangeland/pasture to avoid reinvasion (DPI, 2018).

\section{Nomadacris septemfasciata (Audinet-Serville, 1883) Red locust}

Pest status. This species has been controlled by IRLCO (International Red Locust Control Organization), since the last great invasion of 1929-1944, which affected most African countries south of the equator (Bahana, 2000). Costs were measured in South Africa during two seasons, 1933-34 and 1934-35, and control alone was $£ 933,000$ (around 40 million USD today), even though most of the labor was unpaid (COPR, 1982). Infestations are now less frequent and are mainly limited to the reproduction areas, far from areas of cultivation (Thindwa, 1999). However, large outbreaks occurred between 1994 and 1996, and more recently in 2009 (FAO, News Article: Red Locust disaster in Eastern Africa prevented, 2009).

Habitat and ecology. The red locust is predominantly a grass feeder but will feed on shrubs and trees during outbreaks. It is mainly distributed throughout central and southern Africa; some isolated populations can also be found in the lake Chad basin, the central delta of the Niger River in Mali, and the Cape Verde Islands. Outbreak areas are mainly located in the Great Lakes region of East Africa, in Tanzania, Zambia, Malawi and Mozambique (COPR, 1982; Lecoq et al., 2011). They usually breed in seasonally-flooded plains where there is a mosaic of tall grasses and sedges (e.g., Echinochloa, Hyperrhenia, and Cyperus spp.) and shorter grasses (Cynodon sp.) (Burnett, 1951; Vesey-Fitzgekald, 1955; COPR, 1982). During outbreaks, swarms usually fly low and don't travel more than $20-30 \mathrm{~km}$. Unlike many other locust species, red locusts appear to fly during the day and, in low density, into the wind until they reach areas characterized by large stands of the grass Echinochloa. High-density populations have been recorded to fly downwind, likely because the wind speeds were too high for upwind orientation (Chapman, 1959).

Grazing interactions. The red locust can compete with livestock for forage. In South Africa from 1933 to 1935, red locust damage to grazing areas for sheep and cattle, and to maize and sugar 
cane was valued at $£ 20,000$ (over a million USD today); an additional $\mathfrak{1} 40,000$ was lost due to decrease in animal product outputs through arsenic poisoning used for locust control. However, in recent years, likely due to control in the known breeding areas, red locust oubreaks are minimal and do not result in as much damage to crops and pastures, particularly since biopesticides and spray aircrafts are now used (Thindwa, 1999; FAO, News Article: Red Locust disaster in Eastern Africa prevented, 2009).

\section{Patanga succincta (Johansson, 1763) \\ Bombay locust}

Pest status. Thailand was largely unaffected by locust and grasshopper damage until the early 1960's when a Bombay locust outbreak had a significant impact on maize. This unprecedented outbreak may have been brought on by forest clearing and cereal production (Bullen, 1966). The species numbers and resulting damage grew considerably from 1961 to 1963 with enough individuals to damage 8,000 acres of maize worth $£ 50,000$ at the time. In Thailand today, it is both a major agricultural pest and one of the most popular insect food items commercially produced for human consumption (Phiriyangkul et al., 2015). Corn is grown to feed to locusts that are later sold as food commercially (Hanboonsong et al., 2013). Bombay locusts have been reported damaging a large variety of crops including: coconut, maize rice, bamboo, banana, betel nut, bulrush millet, cashew, cassava, castor, chinse cabbage, citrus, common millet, cowpea, cucumber, Conax canniformis, durian, fig, ginger millet, Gardenia, ginger, ground nut, guava, jujube, mango, mulberry, mung bean, mustard, oil palm, pigeon pea, rambutan, rubber, sorghum, soy, sugar cane, sweet potato, talipot, palm, tea, and tobacco (Roffey, 1979).

Habitat and ecology. The Bombay locust is distributed throughout the Middle East and Asia (COPR, 1982). It inhabits grassy plains of Asia up to about 1,500 m. In Rajasthan, India, it has been associated with Cyperus tuberosus, a sedge sometimes cultivated for its edible tubers. Historically, swarms were recorded in India from 1787 to 1796 and from 1901 to 1908 , but since then only occasional swarms have been reported (COPR, 1982). These uncommon swarms inhabit forests of the Western Ghats during winter and, as temperatures rise, move north or east where they disperse and reproduce after rains. In these areas, Bombay locusts have been recorded to oviposit in grasslands, millet fields, and embankments between farm fields (COPR, 1982).

Grazing interactions. Conversion of forest to grass and cropland has likely increased Bombay locust populations in Thailand. Deforested fields with the grass "lalang" (Imperata sp.) support locust densities up to 20-50 per $\mathrm{m}^{2}$. In Malaysia, high locust abundance occurs in land cleared for rice, because locusts feed on the grasses that initially grow there, but populations diminish with heavy weeding over time in rice fields and they are not a significant rice pest (COPR, 1982).

\section{Subfamily Gomphocerinae-Clade B Gomphocerus sibiricus (Linnaeus, 1767); Synonym Aeropus sibiricus \\ Siberian locust}

Pest status. This locust is one of the most serious agricultural pests in the eastern regions of the European part of the former USSR: the southern forest, forest-steppe, and steppe zones of Kazakhstan and Siberia. It is also one of the most important pests of Xinjiang province in northwestern China (Yang and Wang, 2004). The larvae and adults severely damage summer sowings of wheat, rye, oat, barley, and to a lesser extent winter rye, corn, panicum, mogar, buckwheat, tobacco, potato, cabbage, mustard, hemp, flax, and other agricultural crops, and also pastures and haysag [AgroAtlas - Pests - Aeropus sibiricus (L). - Siberian locust (Siberian grasshopper)., 2003].

Habitat and ecology. Most locusts species are found in lowerelevation environments, however the Siberian locust range includes high mountains (between 2,000 and 2,800 m) ranging from West Siberia to the Atlantic coast (Gosálvez and LópezFernández, 1981). In the subalpine grasslands of Switzerland, it dominates habitats with short grasses (Spalinger et al., 2012). In the Irkutsk region of Russia, it is often associated with Agropyrum cristatum (crested wheatgrass) (Vinokurov and Rubtzov, 1930). It is capable of living in low altitude as well and can be found in desert steppes and meadow steppes. Siberian locusts can regulate the level of stress resistant substances, like linoleic acid, in response to fluctuating temperatures. This adaptation is important under the trend of climate warming as outbreaks tend to be more persistent during warmer weather (Li et al., 2014). The adults mate in August (Bouchard, 1998) and females lay egg pods containing 7-10 eggs, and oviposit an average of 11 times. The Siberian locust is univoltine and hatching usually takes place late the following spring (Il'enko, 1930).

Grazing interactions. In Switzerland, this species does not appear to be affected by wild ungulate grazing (Spalinger et al., 2012). However, sheep may impact population dynamics (GueguenGenest and Gueguen, 1987).

\section{Subfamily Oedipodinae-Clade B Aiolopus simulatrix (Walker, 1870); Synonym Aiolopus savigny (Krauss, 1890) (Moussi et al., 2011) Sudan plague locust}

Pest status. Several members of this genus are economically important and are widely distributed from agriculture rangelands to semi-desert regions (Bughio et al., 2014). In Sudan, A. simulatrix is the most devastating pest of cereal crops (Joyce, 1952; Song, 2011). In the Sahelian region, this locust migrates on long-range diurnal (Chapman, 1976) and nocturnal flights along with the Senegalese locust, Oedaleus senegalensis, following the winds associated with the Intertropical Convergence zone (Riley and Reynolds, 1983). It forms impressive migratory swarms, but the existence of hopper bands is not well-recorded (Song, 2011).

Habitat and ecology. The Sudan plague locust is a grass feeder, distributed in Anatolia, Southern Asia, and Central and Northern 
Africa (Moussi et al., 2011; Kaya et al., 2015). A community analysis comparing acridids present in steppes or oasis in Algeria found that this locust was the only species present across these different vegetation assemblages. It was commonly found in halophilic vegetation (steppes) as well as irrigated cultures (oasis) (Moussi et al., 2011). It has one generation per year with adults peaking in June (Moussi et al., 2011) and it favors areas of bare clay soil with large cracks (Riley and Reynolds, 1983).

Grazing interactions. Given its natural and extensive presence in grasslands, the Sudan plague locust is very likely to compete with livestock for forage, although that effect, to our knowledge, has not been measured (Shen et al., 2009; Wang et al., 2010).

\section{Ceracris kiangsu (Tsai, 1929) Yellow-spined bamboo locust}

Pest status. This locust is a pest of cereal crops and bamboo in South China, and is especially economically important in the Hunan province (COPR, 1982). Banana, maize, millet, rice, sorghum and other crops are also attacked (COPR, 1982 and references therein). In 2015, Laos experienced an unprecedented outbreak, which impacted 20,000 people (Locust control campaign in northern Laos, 2016).

Habitat and ecology. The yellow-spined bamboo locust can be found in India and Thailand but is mainly concentrated in southern China where it is a serious pest of grain crops (Uvarov, 1977) and bamboo leaves (COPR, 1982). Most eggs are laid on southeast facing mountain slopes at 300-400 m. Preferred host plants include many species of bamboo, but it will also feed on other grasses including wild grasses and cereal crops. It has also been recorded eating, palms, and a handful of herbaceous plants (COPR, 1982 and references therein). This locust engages in puddling behavior in the presence of human urine and is attracted to several componets of urine, especially $\mathrm{NaCl}$ (Shen et al., 2009). Ongoing research is exploring the potential of these results to develop baits for control in China (Yu et al., 2011a,b)

Grazing interactions. As C. kiangsu has principally been reported only as a pest of bamboo and cereal crops in Asia, no substantial interactions between grazing and this species are currently known.

\section{Chortoicetes terminifera (Walker, 1870) Australian plague locust}

Pest status. The first outbreaks of the Australian Plague locust were recorded in the early 1870s, with earlier problems in the 1840 s being attributed to the small plague grasshopper, Austroicetes cruciata (Saussure, 1888) (Deveson, 2012). Today the Australian plague locust is among the most significant and widespread agricultural pests in the country (Hunter, 2004). An extensive plague in the 1930s initiated a national research approach to address the "grasshopper problem" (Deveson, 2011). Another significant plague occurred in the 1950s, but it was the 1973-74 plague extending through New South Wales, northern Victoria, and southern South Australia that provided the impetus to develop the Australian Plague Locust Commission (APLC). Since then, there have been five plagues, roughly spaced every 10 years. One of the worst, and most recent, was the 2010 plague with about 2,000 landholders reporting high-density bands (Deveson, 2011). Since 2010, there have been some localized outbreaks, but the 2017-18 season had among the lowest locust numbers recorded by the APLC (Locusts - Department of Agriculture and Water Resources). Australian plague locusts impact a variety of crops including cereal crops, clover, cotton, potatoes, sugar cane, orchards, vegetables, and pasture grasses (COPR, 1982).

Habitat and ecology. Ceracris terminifera is distributed throughout the arid and semi-arid regions of Australia, which is most of the country, excluding the wetter coastal regions. A combination of molecular and survey data suggest populations are well-connected throughout its range (Deveson and Walker, 2005; Chapuis et al., 2011). Extensive research has been carried out on C. terminifera, starting in the 1930s and continuing through present time, including its migration and life history [e.g., (Key, 1945; Clark, 1950, 1965; Farrow, 1979b; Hunter, 1982; Drake and Farrow, 1983; Wright, 1983; Miller and Simpson, 2010; Graham et al., 2015; Woodman, 2017); reviewed in (Deveson, 2011)]. It is multivoltine with typically 2-3 generations per year; more generations per year leads to exponential growth and outbreaks.

Ceracris terminifera are adapted to arid and semi-arid environments with high temporal and spatial variability in precipitation (Hunter et al., 2001). This locust can persist over dry periods through embryonic diapause or as quiescent eggs or adults and can migrate several hundred kilometers in a single warm night or about $20 \mathrm{~km}$ during a day flight. While these migratory events can lead to unfavorable environments, e.g., flying into the ocean, or areas with no rainfall (Farrow, 1979), they are important for at least some percentage of migrants to find areas of localized rainfall and subsequent green vegetation (Hunter et al. 2001). Field studies revealed that sufficient rains, and corresponding green vegetation, were necessary to enable accumulation of lipids for long distant flight and that $C$. terminifera below a certain body lipid content did not migrate (Hunter et al., 1981). C. terminifera prefers grasses and is often found in perennial tussock grass communities (Hunter, 1989) but will feed on forbs and shrubs if water limited. Lack of water may induce mortality in more arid parts of its range (Bernays and Chapman, 1973). Access to grasses from which they can extract a carbohydrate-rich diet are also likely to be critical to maintain growth in field populations (Clissold et al., 2006), and to build up lipid stores for migration. Therefore, the composition of available vegetation, and not just the amount, is expected to play a significant role on the population dynamics and migratory potential of this species.

Ceracris terminifera exhibits behavioral phase polyphenism (Gray et al., 2009), with crowd-reared nymphs increasing activity and propensity to spend time near conspecifics (Cullen et al., 2012). Antennae tactile stimulation is the most important proximal cue for inducing gregarious behavior (Cullen et al., 2010). Crowd-reared nymphs tend to have increased melanization relative to solitary-reared nymphs; however, this species does not exhibit striking color differences between the phases (Rogers S., unpublished data, pers. comm.). There is some evidence that clumped resources promote gregarization, 
likely due to increased conspecific interactions. For example, an occupancy model showed there was a higher probability of dispersed populations leading to gregarious outbreaks in desert areas, where vegetation resources are more clumped, relative to grasslands (Veran et al., 2015).

Grazing interactions. The Australian plague locust is often found in livestock grazing areas due to its preference for grasses and low woody vegetation cover (Clark, 1950). Such rangelands are likely required to support population build up leading to outbreaks, which then spillover into proximate and distant grazing and crop lands (Watts et al., 1982; Symmons, 1984; Wright and Symmons, 1987). The importance of rangelands for C. terminifera populations may be due to a number of factors including bare ground areas for thermoregulation and oviposition, as well as plant species and quality optimal for locust growth. For example, C. terminifera tend to select sites for oviposition where there is about $50 \%$ bare ground and short vegetation (Clark, 1947). Indeed, historic deforestation and creation of new grasslands likely allowed the expansion of this species in the late 1800s through to present day (Deveson, $2011,2012)$. In large numbers, C. terminifera can wipe out grazing paddocks, leaving limited forage for livestock and negatively impacting landholders. However, locust control can also negatively impact the livestock industry through the effects of pesticide residues on livestock (Hooper, 1998).

\section{Gastrimargus musicus (Fabricius, 1775) Yellow-winged locust-Australia}

Pest status. This locust is an important pest in areas which receive summer rainfall in northern Australia where periodic plagues connected to increased rainfall historically devastated home gardens and farms (Jenkins, 1968). The species has also been recorded as an occasionally significant pest of sugar cane (Long and Hensley, 1972) and is known to attack cotton, maize, Monterey pine, pineapple, Rhodes grass, sorghum, Sudan grass, sugar cane, vine, orchards, and pasture (COPR, 1982). Sporadic outbreaks in recent decades have caused significant damage to pasture albeit at local scales (Kathy, 2006; Gartry and Edwards, 2016; Beavan, 2017; Stanley, 2018).

Habitat and ecology. The yellow-winged locust gets its name from conspicuous black and yellow hind wings. The species is found in coastal and subcoastal areas of Australia with more than $500 \mathrm{~mm}$ of annual rainfall and patchy habitat containing tall grass with bare ground. It reportedly prefers the pasture grasses Cynodon dactylon and Paspalum dilatatum (COPR, 1982; Bernays and Hamai, 1987) and is common in rangelands, pastures, parks, and lawns. At low densities individuals are usually predominantly green but when swarming they become brown. Number of generations per year depends on geography, with normally two generations in central Queensland but only one in the table lands of New South Wales (DPI, 2019).

Grazing interactions. Increases in population levels of this locust are most likely driven by deforestation and livestock grazing that result in a combination of tall and short grasses for shelter and food, and bare ground for oviposition (Uvarov, 1977). Egg pods are preferentially laid on bare, compact soil especially on overgrazed pasture (DPI, 2019). Continued sporadic outbreaks occasionally breaking into swarming over the last several decades have cause considerable damage to pasturelands with occasional swarming in Western Australia, but swarming frequency is less common, and swarms are more localized and slower moving relative to the Australian plague locust (DPI, 2019).

\section{Locusta migratoria migratoria (Linnaeus, 1758); Locusta migratoria migratorioides (Reiche and Fairmaire, 1849) \\ Migratory locust}

Taxonomic notes. The migratory locust is the most widely distributed grasshopper species in the world. Historically, many subspecies of Locusta migratoria were recognized based on their geographic range. A phylogeographic analysis (Ma et al., 2012) collapsed all subspecies into just two corresponding to the northern and southern lineages: the Asian Migratory Locust, L. migratoria migratoria (Linnaeus, 1758), and the African Migratory Locust, L. migratoria migratorioides (Reiche and Fairmaire, 1849).

Pest status. The migratory locust is present across the entire temperate and tropical Eastern hemisphere. Its northern limit corresponds roughly with the southern edge of the coniferous forest of Eurasia and it extends as far South as New Zealand. In the West it can be found as far as in the Azores and in the East as far as the Fiji (COPR, 1982).

Plagues from the Asian migratory locust were reported in China from $200 \mathrm{BC}$, typically in association with droughts and flood events (Stige et al., 2007; Tian et al., 2011). Its presence in Australia is more recent: before 1973 it was an uncommon species of the coastal and subcoastal region of Australia with a few scattered records from inland. In 1973-76, an important outbreak occurred in the Central Highlands district of Queensland (Farrow, 1979a). It is one of the most important agricultural pests in the countries of the former Soviet Union particularly Russia, Kazhakhstan, and Uzbekistan (Latchininsky, 2013). The Asian migratory locust can fly distances of over $1,000 \mathrm{~km}$ and infest very large areas, for example over 1 million ha in 1946 (Latchininsky, 2013). Outbreak densities can reach over 10,000 individuals $\mathrm{m}^{-2}$ for early stadium nymphs as reported in China in 2003 (Tanaka and Zhu, 2005).

Historically, the African migratory locust only gave rise to plagues in the Middle Niger flood plains and surrounding Sahelian steppes. There, conditions enable four to five generations to take place annually. Movements of swarms generally follow the movement of the inter-tropical convergence zone. Damages are typically reported for the whole invasion area, and usually concern cereals, but also other plants when grasses are not available (e.g., banana, pineapple leaves, palms, etc.). Recent rapid agricultural development, particularly broad-acre cultivation of cereal summer crops has caused population upsurges in new areas, which have occasionally led to outbreaks and plagues. Some outbreaks appear to have been a reaction to the initial disturbance and have never recurred while others recur when meteorological conditions are favorable (Farrow, 
1987). Outbreaks have been reported in Mali, Chad, Sudan and Madagascar (Farrow, 1987).

In contrast to the desert locust, gregarization is a slower process for the migratory locust. Locusts are only partially gregarized even after $64 \mathrm{~h}$ of crowding (Guo et al., 2011; Ma et al., 2011, 2015). Similar to the desert locust, biogenic amines are involved in phase change polyphenism. However, their role is complex, and the functional significance of change in their concentration is not fully understood. For instance it appears that serotonin is linked to both behavioral solitarization and gregarization (Guo et al., 2011; Ma et al., 2011; Cullen et al., 2017). In the past two decades, advances in molecular research have demonstrated that full phase change is accompanied by extensive changes in gene expression (Kang et al., 2004; Guo et al., 2011).

Habitat and ecology. The Asian migratory locusts are typically associated with river deltas, and coastal plains that present intermittently flooded areas. They favor grasses such as Panicum sp. Phragmites communis, Artemisia sp. and Polygonum. In many areas, shifting cultivation practiced for a few years before abandoning the land has produced food and shelter, conditions that promotes transformation into the gregarious phase (Uvarov, 1936).

The African migratory locust favors area of $10-15 \%$ bare ground with mixed association of Ctenium elegans, Cenchrus biflorus, Eragrostis tremula for breeding in the late rainy season. The Niger flood plains provide special conditions because the retreating floods allow the locust to survive during the dry season but also to breed. Near the Lake Chad basin, Cynodon is the favored host plant. Shifting cultivation in the Sahel also led to the development of abandoned land with bare areas that retain millet, sorghum, and Cenchrus biflorus which are favored host plants.

Grazing interactions. In Mali, Chad, Sudan and Madagascar, people have likely increased migratory locust population through agricultural and pastoral activities. For instance, the Sahara Desert used to be unsuitable for this species, but human activities starting in the 1980's, particularly the introduction of irrigated crops under pivoting sprayers favored population increases (Benfekih et al., 2002; Benfekih and Petit, 2010). In the Touat region alone, cropped areas increased by more than $60 \%$ from 1984 to 1989 (Benfekih et al., 2002).

While the migratory locust is mostly considered a pest of cereal crops, a study in Tibet showed that early instars (1st and 2nd instar nymphs) fed mostly on pasture grass (Qing and Chunxian, 2008). After the 3rd instar they switched to barley and winter wheat. However, treating pastures and rangeland can cause serious health issues to livestock, as illustrated in China in the Xinjinan Uygur Autonomous region where infestation areas are huge and spraying by aircraft problematic because of livestock (Tanaka and Zhu, 2005).

\section{Locustana pardalina (Walker, 1870) Brown locust}

Pest status. The brown locust is among the most serious pests in South Africa, attacking cereals and pastures (Price and Brown, 2000; Todd et al., 2002). Controlling the brown locust has cost the
South African taxpayer millions of Rands annually. The massive outbreak in 1985-86 cost over R50 million to control (equivalent to \$25 million USD at the time), while the outbreak in 1995-96 cost $\sim$ R14 million ( $\$ 3.5$ million USD at the time). Due to locust control, the true swarming phase with extensive migrations has been limited in recent decades (COPR, 1982; Price and Brown, 2000; Todd et al., 2002). However, this species has been outbreaking more frequently than other locust species in South Africa, and these non-swarming outbreaks last for 7-11 years. De Villiers (1988) hypothesized that the lack of major swarms, and associated boom-bust population cycles, may increase the overall impacts of brown locusts on agriculture because outbreaks are found more consistently across years.

Habitat and ecology. This grass-feeding locust is found in the Karroo region of the Cape province of South Africa and neighboring parts of Free State and Namibia. It is primarily found in arid regions where rainfall is limited and erratic, the vegetation is sparse and short, and where it feeds mostly on dwarf grasses (COPR, 1982). Shifting rainfall patterns have been correlated with range expansion and contraction (Kieser et al., 2010). Increased summer rainfall $(>150 \mathrm{~mm})$ resulting in taller and more dense grasses was correlated with decreased locust populations, while drier conditions $(100-150 \mathrm{~mm})$ were associated with range expansion. During outbreaks the species used to spread throughout southern Africa, as far north as $16^{\circ} \mathrm{S}$.

Grazing interactions. The brown locust has significant impacts on livestock pastures. In the 1970s, the most severe damage was in sheep grazing areas (Botha, 1974; COPR, 1982), when organochloride control options were tested but were shown to be impractical for sheep (Botha, 1974). Sheep grazing, in turn, may promote brown locust outbreaks. High sheep stocking rates since European colonization have been associated with land degradation in South Africa (Keay-Bright and Boardman, 2006) which creates shorter, sparser grasses that brown locusts prefer (COPR, 1982; Kieser et al., 2010). Currently, there is no active field monitoring program to locate hopper bands. Instead, control efforts rely on the legal requirement of farmers to report outbreaks on their property, after which broad-spectrum insecticides are applied on aggregated immature locusts or roosting mature swarms (Crooks and Cheke, 2014).

\section{Oedaleus decorus asiaticus (Bey-Bienko, 1941) Mongolian locust}

Taxonomic notes. Bei-Bienko and Mishchenko (1951) distinguish asiaticus from decorus, but Ritchie (1981) maintains that asiaticus is a subspecies of decorus (O. decorus asiaticus) (Bei-Bienko and Mishchenko, 1951; Ritchie, 1981). We use O. asiaticus to maintain consistency with the literature that has focused on this species in China. Mitochondrial genome analyses have shown that $O$. asiaticus is closely related to the migratory locust, L. migratoria (Ma et al., 2009).

Pest status. Prior to the 1970's, O. asiaticus was rarely reported to cause agricultural damage. However, it is now considered a dominant pastoral pest across the northern Eurasian steppe (Jiang et al., 2003; Kang et al., 2007). For example, in 1999, 
an outbreak was recorded to span six million hectares in Inner Mongolia, China with densities of 100 individuals $\mathrm{m}^{-2}$; in 2002, densities of over 1,000 O. asiaticus $\mathrm{m}^{-2}$ were reported (Wang, 2004). Feng et al. (1994) calculated that at a density of 11 individuals $\mathrm{m}^{-2}$, Inner Mongolian grasshoppers consume about $15 \%$ of the aboveground biomass or about $200 \mathrm{~kg} / \mathrm{ha}$ of fresh forage annually, suggesting the outbreak numbers would decimate all vegetation. Northern and northeastern China is one of the most important grassland-based animal husbandry areas for the country (Li et al., 2008) and O. asiaticus and other grasshoppers compete with sheep and cattle for forage Accordingly, locusts are ranked as one of the most serious pests due to its capacity to devastate grassland productivity (China Ministry of Agriculture, 2012) and the country has implemented an ongoing management program including pesticides, biopesticides, and chickens as locust predators ( $\mathrm{Xu}$ et al., 2014; Zhang and Hunter, 2017).

Habitat and ecology. Oedaleus asiaticus is found across the Eurasian steppe, including China, Mongolia, and Russia (Ritchie, 1981). It is primarily a grass feeder, especially Stipa spp. Several studies have demonstrated $O$. asiaticus is most abundant in Stipa-dominated landscapes and that it prefers and has the highest growth and survival when eating this grass (Han et al., 2008; Cease et al., 2012; Huang et al., 2015, 2016, 2017a). A gut transcriptome analysis revealed Stipa krylovii has a higher use efficiency by $O$. asiaticus relative to other common grasses, including Leymus chinensis, which is often co-dominant with Stipa in this species' range (Huang et al., 2017b). Accordingly, $O$. asiaticus has a greater olfactory response to plants in the Poaceae family relative to forb feeders (Chen and Kang, 2000). Several additional studies have investigated the nutritional ecology of this species. For example, field cage studies revealed that $O$. asiaticus maintains phosphorus homeostasis by changing absorption and excretion rates, but other mechanisms may be more important for nitrogen balance (Zhang et al., 2014). Based on a combination of field surveys in Inner Mongolia and climate data, O. asiaticus was most prominent on the temperate bunchgrass steppe at flat sites or sites with southeastern slopes at an elevation of 1300-1400 m, sites with chestnut soil containing about 60-70\% sand, and sites with moderate (30-50\%) vegetation coverage (Huang et al., 2015). It is univoltine with one generation per year, hatching in early June and undergoing five juvenile instars prior to molting into adults in mid-July (Ma et al., 2009; Cease et al., 2010). With climate warming, O. asiaticus is likely to hatch earlier, develop faster, and shift northward (Guo et al., 2009; Wu et al., 2012), though its capacity to withstand high temperatures as eggs may be limited (Hao and Kang, 2004).

Oedaleus asiaticus is a non-model locust (Song, 2011) with high-density outbreaks and swarms comprised predominantly of darker, brown morphs (Jiang et al., 2003). Brown morphs have increased relative investment in thorax and hind legs along with higher metabolic rates (Cease et al., 2010). Female brown morphs are larger, on average, than green morphs (males have not been compared), consistent with some locusts (D. maroccanus, L. pardalina, and C. terminifera), but in contrast of others $(S$. gregaria, N. septemfasciata, L. migratoria) (Uvarov, 1966, 1977;
Cease et al., 2010). Higher densities induce O. asiaticus to increase some morphological traits predicted to enhance migration: larger wings and a shift in relative mass from abdomen to thorax (Cease et al., 2010).

Grazing interactions. Due to its competition with livestock (Liu et al., 2013a), many studies have looked at the relationship between livestock grazing and O. asiaticus density. In Stipa grandis, Leymus chinensis, and Aneurolepidium chinense steppes with $320-350 \mathrm{~mm}$ annual precipitation and 1,000-1,050 $\mathrm{m}$ in elevation in the Xilingol region of Inner Mongolia, stocking rate tends to decrease diversity and increase abundance of grasshoppers, particularly O. asiaticus (Kang and Chen, 1995; Xinghui and Hongchang, 1997; Cease et al., 2012) across a wider precipitation gradient $(200-400 \mathrm{~mm})$, livestock grazing had the greatest impact at the driest sites, where it similarly decreased grasshopper diversity and increased abundance of $O$. asiaticus (Hao et al., 2015). There are likely many factors driving this pattern, but several studies suggest host plant nutrition is a key driver. While livestock grazing can concentrate nitrogen due to livestock nitrogen excretion, in Inner Mongolia, continuous high stocking rates tend to decrease soil and plant nitrogen. The mechanism is two-fold: (1) increased wind erosion due to more bare soil, and (2) sheep are kept in sheepfolds at night where substantial manure is accumulated. The manure is burned for household fuel and thus the nutrients are not returned to the landscape (Giese et al. 2013). O. asiaticus prefer low nitrogen Stipa grandis collected from heavily grazed areas relative to ungrazed fields (Cease et al., 2012). This pattern matches with the species of host plants preferred by O. asiaticus. Counterintuitively, even though Stipa spp tend to have lower nitrogen and protein contents than Leymus and other common grasses, it is generally preferred by O. asiaticus (Liu et al., 2013a; Cease et al., 2017; Huang et al., 2017b). This is likely due to its low protein and high carbohydrate content; although secondary metabolites may also play a role (Li et al., 2019). These carbohydrate-biased diets increase growth rate, survival, and migratory capacity for O. asiaticus (Cease et al., 2012, 2017).

\section{Oedaleus senegalensis (Krauss, 1877)}

\section{Senegalese locust, or Senegalese grasshopper}

Pest status. This species was not widely recognized as a pest until 1974 when, together with other grasshopper species, it infested 3.5 million hectares in West Africa and was responsible for the loss of 368,000 tons of agricultural production (Bernardi, 1986). It is now considered a major pest in the Sahel area (Maiga et al., 2008) and very often dominates grasshopper communities. In central Sudan, adults can reach densities of over 3,400 green adults/ha and 5,500 brown adults/ha (Elamin et al., 2013). It attacks several subsistence crops, particularly millet.

The lifecycle and survival strategies of $O$. senegalensis have evolved to include migration following shifts in the intertropical convergence zone (ITCZ) and embryonic diapause in the dry season. The alternation between outbreaks and recession periods seems to be related to the high spatiotemporal rainfall variability in the Sahel and various models designed to monitor the population dynamics of this species have been published 
(Launois, 1978, 1979; Holt and Colvin, 1997; Fisker et al., 2007; Axelsen, 2009; Maiga et al., 2009; Bal et al., 2015). However, the variability in outbreaks and phase change polyphenism are not well-understood (Maiga et al., 2008; Song, 2011).

Habitat and ecology. Oedaleus senegalensis is a grass feeding Sahelian grasshopper. Its distribution range covers the whole Indo-Saharan zone, from the Atlantic, including Cape Verde, to central India (Maiga et al., 2008). In the Sahel, this species is adapted to the long dry season and summer rains arising from the Intertropical Convergence Zone (ITCZ). It typically has three generations (G1 to G3) per year, which follow the rains north and then south again to stay in an optimal humidity range. Adults following the front of the ITCZ can migrate up to $350 \mathrm{~km}$ a night (Cheke, 1990). G3 adults return to the southern range and lay eggs that undergo a 7-8 month long embryonic diapause during the long dry season. Interestingly the hatching pattern of non-diapausing and diapausing eggs is quite different. Non-diapausing eggs hatch in high numbers over a brief period at the end of the rainy season, while diapausing eggs hatch in small numbers over a longer period during the rainy season. The latter most likely constitutes a "bet-hedging" adaptation to the unpredictability of the onset of summer rainsthe first set of rain events are frequently followed by periods of drought (Maiga et al., 2010). No controlled studies on phase change have been done for $O$. senegalensis. However, nymphal marching bands and loose swarms have often been recorded (Batten, 1969), and high density outbreaks have been reported to have brown and black coloration as compared to low density populations with predominantly green coloration (Ritchie, 1978; Le Gall et al. under review). In the West African Sahelian region, O. senegalensis colonizes annual grass communities dominated by species such as Cenchrus biflorus (referred to as "cramcram" in the francophone countries of the Sahel), Aristida mutabilis, Aristida adscensionis ("6 weeks threeawn"), Eragrostis spp ("lovegrass" or "canegrass"), Dactyloctenium aegyptium ("Egyptian crowfoot grass"), Schoenefeldia gracilis. They also consume a few woody and perennial species like Aristida pallida (Maiga et al., 2008).

Grazing interactions. While $O$. senegalensis is widely recognized as a major pest of cereal crops like millet, it is actually more abundant in grazed and fallowed fields (Amatobi et al., 1988; Toure et al., 2013; Word et al., 2019), where it is very likely to compete with livestock. In general cultivation and afforestation affect grass-feeding grasshoppers negatively, but $O$. senegalensis is less sensitive to it than some other species (Amatobi et al., 1988), perhaps because of its ability to feed on cereals.

\section{DISCUSSION}

In reviewing the livestock grazing interactions with the 19 grasshopper species currently considered locusts (Cullen et al., 2017), we found that land use has strong effects on many locust species (Table 1). This pattern is illustrated by correlations between outbreak frequency and changes in agricultural practices. However, the mechanisms underpinning these relationships are often unknown and the directionality is often species-specific. Most locusts originate in grasslands. These ecosystems are subject to expanding agriculture, urbanization, energy development, and desertification, making them among the most threatened biomes on Earth (Hoekstra et al., 2005). For some mix and grass-feeder species like the Moroccan locust or the red locust, this increase in anthropogenic change, alongside modern control practices, has led to a decrease in outbreak frequency (Thindwa, 1999; Benfekih et al., 2002). This also appears to have been the case for the Rocky Mountain grasshopper, Melanoplus spretus, which destroyed vast quantity of crops throughout the western and central portion of the United States and Canada during the mid-1800s. The species declined rapidly in the late 1800s and agricultural practices likes tillage, irrigation, introduction of cattle, plants, and birds into grasslands are thought to be responsible for its extinction (Lockwood and Debrey, 1990). However, in many other cases because cropland expansion includes cereals that are readily consumed by mix- and grass-feeders, it yielded an increase in outbreak frequencies, as seen with the Bombay locust (Bullen, 1966), the spur-throated locust (Casimir and Edge, 1979), and the Central American locust (Poot-Pech, 2016).

One mechanistic link between livestock grazing and locust populations is the conversion of wooded areas to open fields, including patchy grasslands, more desirable to locusts (Clark, 1950). For example, early swarms of the Australian plague locust, Chortoicetes terminifera, in the late 1800's may have been promoted by the introduction of European livestock and agriculture to Australia (Deveson, 2012). The Mongolian locust, Oedaleus asiaticus, was rarely reported to have economically important outbreaks prior to the 1970's; increased outbreaks may coincide with increased livestock populations in Inner Mongolia, China (Robinson et al., 2017). Thus, land use and cover change has potentially contributed to the emergence of new locust species that previously did not exhibit strong locust phase change characteristics, likely in conjunction with shifting climate. For instance, the Senegalese grasshopper was not reported as a pest until it first started outbreaking in the 1970's and is now considered the main pest of millet in the Sahel, exhibiting locust characteristics like density-dependent color change and migrations (Popov, 1980; Maiga et al., 2008). Similarly, the Peruvian locust was only known as a non-swarming grasshopper until an upsurge in Peru in 1983-84, subsequently gregarized individuals invaded several Peruvian states from 1997 to 2003 (Duranton et al., 2006). However, to our knowledge, land use/cover change has not been tested as a causal link to increased outbreak frequency in either species and more research is needed to uncover the potential mechanistic links.

Increasing grazing pressure and agricultural intensity may inadvertently be creating a nutritionally optimal environment for locusts through soil degradation. In addition to presenting bare areas favorable to egg laying and thermoregulation, degraded pastures may harbor plants with low protein:carbohydrate ratios that are favorable to locusts. Soil erosion typically decreases soil nitrogen resulting in low nitrogen plants (for a mechanistic description between grazing and plant nitrogen, see O. asiaticus section) (Jie et al., 2002; Giese et al., 2013). Since most 
TABLE 1 | Worldwide Locust Species, adapted from Cullen et al. (2017).

\section{Species, subfamilies, and clades by Common name \\ feeding guildes \\ Geographic range \\ Grazing interactions reported in Nutritional preferences the literature}

\section{FORB- AND/OR TREE-FEEDING LOCUSTS}

Calliptamus italicus (Linnaeus, 1758)

Italian locust

Europe and Central Asia

- Weak but present with livestock in NA pastures

Anacridium melanorhodon (Walker, 1870) Sahelian tree locust

Cyrtacanthacridinae

North and Central Africa, - Weak but present with livestock in NA

Middle East

pastures

- Nutrient cycling

\section{MIX-FEEDING LOCUSTS (GRASSES, FORBS, AND/OR TREES)}

Schistocerca cancellata (Serville, 1838) South American locust South America

Cyrtacanthacridinae

Clade D

Schistocerca gregaria flaviventris

(Burmeister, 1838)

Cyrtacanthacridinae

Clade D

Schistocerca gregaria gregaria (Forskål,

1775)

Cyrtacanthacridinae

Clade D

Schistocerca interrita (Scudder, 1899)

Cyrtacanthacridinae

Clade D

Schistocerca piceifrons peruviana (Lynch

Arribalzaga, 1903)

Cyrtacanthacridinae

Clade D

Dociostaurus maroccanus (Thunberg,

1815)

Gomphocerinae

- Clade B

\section{GRASS-FEEDING LOCUSTS}

Austracris guttulosa (Walker, 1870)

Cyrtacanthacridinae

Clade D

Nomadacris septemfasciata

(Audinet-Serville, 1883)

Cyrtacanthacridinae

Clade D

Patanga succincta (Johansson, 1763)

Cyrtacanthacridinae

Clade D

Gomphocerus sibiricus (Linnaeus, 1767) Siberian locust

Gomphocerinae

Clade B

Aiolopus simulatrix (Walker, 1870)

Oedipodinae

Ceracris kiangsu (Tsai, 1929)

Oedipodinae

Clade B

Chortoicetes terminifera (Walker, 1870)

Oedipodinae

Clade B

Gastrimargus musicus (Fabricius, 1775) Yellow-winged locust Australia Oedipodinae

Clade B

Central American
Desert locust (southern Southern Africa (N.B., race)

typically non-swarming)

Desert locust (northern Southern Europe, North race) Africa, Middle East, Indian subcontinent

Peruvian locust Peru

NA

locust

Moroccan locust

Peru, Ecuador, Colombia Venezuela, Panama, Trinidad and Tobago

North Africa, Europe, Caucasus
- Not reported

- Not reported

- Attack fodder

- Non-target effects of chemical control

- Camels accelerate gregarization

- Conversion of forest to grassland has increased capacity for gregarization

- Attack fodder

- Present with livestock in pastures (particularly if overgrazed)
Carbohydrate-biased

P1:C2 (Overson et al., in prep)

Carbohydrate-biased

P1:C1.25 (Simpson et al., 2002)

\begin{tabular}{|c|c|c|c|}
\hline Spur-throated locust & Australia & $\begin{array}{l}\text { - Attack fodder } \\
\text { - Present with livestock in pastures } \\
\text { when swarming }\end{array}$ & NA \\
\hline Red locust & $\begin{array}{l}\text { Sub-Saharan and Southern } \\
\text { Africa }\end{array}$ & $\begin{array}{l}\text { - Attack fodder } \\
\text { - Present with livestock in pastures } \\
\text { - Non-target effects of } \\
\text { chemical control }\end{array}$ & NA \\
\hline Bombay locust & India, South-East Asia & $\begin{array}{l}\text { - Conversion of forest to grassland } \\
\text { has increased capacity for } \\
\text { gregarization }\end{array}$ & NA \\
\hline Siberian locust & $\begin{array}{l}\text { Europe, Caucasus, North } \\
\text { Asia }\end{array}$ & - Present with livestock in pastures & NA \\
\hline Sudan plague locust & North and Central Africa & - Present with livestock in pastures & NA \\
\hline $\begin{array}{l}\text { Yellow-spined bamboo } \\
\text { locust }\end{array}$ & East Asia & - Not reported & NA \\
\hline Australian plague locust & Australia & $\begin{array}{l}\text { - Conversion of forest to grassland } \\
\text { has increased capacity for } \\
\text { gregarization } \\
\text { - Present with livestock in pastures }\end{array}$ & $\begin{array}{l}\text { Field populations are consistently } \\
\text { carbohydrate-biased P1:C1.4 to } \\
\mathrm{P} 1: 2.2 \mathrm{C} \\
\text { (Cease et al, and Lawton et al. } \\
\text { unpublished data) }\end{array}$ \\
\hline Yellow-winged locust & Australia & $\begin{array}{l}\text { - Conversion of forest to grassland } \\
\text { has increased capacity for } \\
\text { gregarization } \\
\text { - Present with livestock in pastures }\end{array}$ & NA \\
\hline
\end{tabular}

(Continued) 
TABLE 1 | Continued

\begin{tabular}{|c|c|c|c|c|}
\hline $\begin{array}{l}\text { Species, subfamilies, and clades by } \\
\text { feeding guildes }\end{array}$ & Common name & Geographic range & $\begin{array}{l}\text { Grazing interactions reported in } \\
\text { the literature }\end{array}$ & Nutritional preferences \\
\hline $\begin{array}{l}\text { Locusta migratoria migratoria (Linnaeus, } \\
\text { 1758) } \\
\text { Oedipodinae } \\
\text { Clade B }\end{array}$ & Asian migratory locust & $\begin{array}{l}\text { West and Central Asia, } \\
\text { Eastern Europe }\end{array}$ & $\begin{array}{l}\text { - Early instars present with livestock } \\
\text { in pastures }\end{array}$ & $\begin{array}{l}\text { Carbohydrate-biased } \\
\text { P1:C1.4 (Chambers et al., 1995) }\end{array}$ \\
\hline $\begin{array}{l}\text { Locusta migratoria migratorioides (Reiche } \\
\text { and Fairmaire, 1849) } \\
\text { Oedipodinae } \\
\text { Clade B }\end{array}$ & African migratory locust & $\begin{array}{l}\text { Mainland Africa and Atlantic } \\
\text { Islands, Madagascar, South } \\
\text { and East Asia, Australasia, } \\
\text { Tibetan plateau }\end{array}$ & & \\
\hline $\begin{array}{l}\text { Locustana pardalina (Walker, 1870) } \\
\text { Oedipodinae } \\
\text { Clade B }\end{array}$ & Brown locust & Southern Africa & $\begin{array}{l}\text { - Present with livestock in pastures } \\
\text { - Non-target effects of } \\
\text { chemical control }\end{array}$ & NA \\
\hline $\begin{array}{l}\text { Oedaleus asiaticus (Bey-Bienko, 1941) } \\
\text { Oedipodinae } \\
\text { Clade B }\end{array}$ & Mongolian locust & Northern Asia & $\begin{array}{l}\text { - Present with livestock in pastures } \\
\text { (particularly if overgrazed) }\end{array}$ & $\begin{array}{l}\text { Carbohydrate-biased } \\
\text { P1:C2(Cease et al., 2012) }\end{array}$ \\
\hline $\begin{array}{l}\text { Oedaleus senegalensis (Krauss, 1877) } \\
\text { Oedipodinae } \\
\text { Clade B }\end{array}$ & Senegalese locust & North Africa, Middle East & - Present with livestock in pastures & $\begin{array}{l}\text { Carbohydrate-biased } \\
\text { P1:C1.6 (Le Gall et al, } \\
\text { under review) }\end{array}$ \\
\hline
\end{tabular}

nitrogen in plants, particularly grasses, is found in the form of protein, and protein and carbohydrate tend to be negatively correlated, this translates into low protein, high carbohydrate plants (Loaiza et al., 2017). In contrast to the N-limitation hypothesis (White, 2012), emerging evidence suggests that locusts are more likely to be carbohydrate-limited in field populations. For example, marching bands of $S$. cancellata from the recent upsurge ate most readily from dishes containing carbohydrates and rarely stopped at dishes with protein (Medina et al. 2017; Overson et al. unpublished data). Over recent decades, many lab studies have shown multiple locust species select a carbohydrate-biased diet when given the choice and show higher performance around their self-selected low protein, high carbohydrate diet (Raubenheimer and Simpson, 1993; Chambers et al., 1995; Simpson and Raubenheimer, 2000; Simpson et al., 2002).

There are multiple factors that might explain why carbohydrate-biased diets are beneficial for locusts. First, carbohydrate-biased diets may be a requirement for longdistance flight (Hunter et al., 1981; Cease et al., 2017). A defining characteristic of locusts is their capacity to undergo spectacular migrations: swarms can fly hundreds of kilometers in a single night and plagues can span continents. These long-distance flights are fueled primarily from lipid reserves (Weis-Fogh, 1952; Jutsum and Goldsworthy, 1976), which are built with dietary carbohydrates (Walker et al., 1970; Jutsum and Goldsworthy, 1976; Hunter et al., 1981). Insect flying metabolic rates can be 20-100 times that of resting animals and are among the highest known (Rankin and Burchsted, 1992). This high energy demand means their food source pre-and during migration is critical to fueling flight. Second, carbohydrate-biased diets may be important for resistance against parasites and pathogens. For instance, Australian plague locusts are more likely to die of fungal infection when they are restricted to diets high in protein than when they are restricted to diets high in carbohydrates (Graham et al., 2014). Potentially because fungus are better at exploiting protein in the insect's hemolymph, or perhaps because immune function is correlated with lipid levels of the host (Graham et al., 2015). Finally, these diets may help locusts persist in an arid environment because consuming more carbohydrate enhances lipid stores, which can in turn be used as a water reserve, as shown in the migratory locust (Loveridge and Bursell, 1975).

Although the link between land use, plant nutrient content, and locust performance has only experimentally been demonstrated for O. asiaticus (Cease, 2012; Cease et al., 2015), correlation between plant nutrient content and locust density has also been shown for $O$. senegalensis (Word et al., 2019). The connection between plant nutritional landscape and locust outbreaks is thus a promising mechanism to explain the association between agricultural practices and locusts, and is an area for suggested research, particularly for non-model locusts (see Table 1). Furthermore, the presence of locusts in grazed areas leads to strong competition between locusts and livestock, particularly for mix- and grass-feeders. Even tree-feeders, like the Sahelian tree locust, were reported to compete with livestock by attacking shrubs that are a food source for domestic cattle and camels (COPR, 1982). This competition for resources between livestock and locusts has the potential to further degrade soils in over-grazed areas as shown for the brown locust in South Africa (Lea, 1958a,b; De Villiers, 1988; Price and Brown, 2000).

The interactions between decisions regarding land use and locust biology has rippling effects: increased grazing pressure creates optimal environments for locusts, leading locusts to reach higher densities, which promotes gregarization. Gregarization in turn increases locust diet breadth, leading to expansive and diverse crop damage (COPR, 1982; Despland, 2005). One potential explanation for the diet expansion is that gregarious locusts may be more likely to encounter a variety of host plants with varying nutrient contents and, by eating from among these diverse food sources, they can balance nutrient 
requirements (Simpson et al., 2002). Another explanation is eating toxic plants can serve as an anti-predatory strategy, which is linked to the development of density-dependent aposematic coloration seen in some locust species (e.g., $S$. gregaria, Sword et al., 2000; Sword, 2002; Cullen et al., 2017): Gregarious desert locusts are less deterred by plant secondary compounds and ingest more plant toxins than solitarious locusts, they are thus better defended against predators (Despland, 2005; Despland and Simpson, 2005b). Exploring how gregarious locusts expand their diet breadth is another understudied area.

In many cases livestock grazing has positive effects on locust populations, which can lead to food insecurity. However, grasshoppers, including locusts, are dominant herbivores and vital players in grassland ecosystems (Branson et al., 2006). Furthermore, chemical control of grasshoppers and locusts has many undesirable side-effects on livestock health (Botha, 1974; Tanaka and Zhu, 2005), human health (Houndekon and De Groote, 1998; Tingle et al., 2003), and predator communities (Balança and De Visscher, 1997). Therefore, management programs that rely on population monitoring and early intervention, such as chemical treatment as soon as populations start to increase, are more likely to be sustainable (Van Huis et al., 2007; Magor et al., 2008; Zhang et al., 2019). These programs have been aided by rapid progress made in remote sensing techniques that can help detect locust bands and/or potential locust habitat by distinguishing areas of green vegetation from bare soils. For instance, a combination of satellite data to estimate rainfall and vegetation cover, and field survey data to indicate locust outbreaks, can be used to develop predictive models (Cressman, 2013; Piou et al., 2013). These models assist managers in determining the probability of finding locusts in specific areas to more efficiently focus survey efforts.

With a greater understanding of the connections between agricultural practices and locust outbreaks, cultural control options may be viable components of future management programs. For example, habitat manipulation can slow nymphal development, reduce survival and reproduction, or decrease yearly variability in those life history traits (Onsager and Olfert, 2000; Branson et al., 2006). Manipulations to limit pest damage can include direct competition from mammalian herbivores such as livestock for grasshoppers (Onsager, 2000), altering food quality for terrestrial herbivores (Le Gall and Tooker, 2017), manipulating plant composition, and increasing the abundance of natural enemies of grasshoppers (Belovsky, 2000; Joern, 2000). These types of management practices are less developed for locusts but harbor great potential. For example, in West Africa, fallow fields often have more Senegalese grasshoppers than other field types (Toure et al., 2013; Word et al., 2019), likely due, in part, to vegetation nutritionally optimal for locusts growing in those areas (Le Gall et al., under review). Due to limited land availability, fields may be left fallow only when the soil has been depleted and yield is limited, resulting in a low- $\mathrm{N}$ environment and carbohydrate-biased plants. Because locusts require a particularly carbohydratebiased diet (Table 1), bottom up control using knowledge of locust nutritional requirements may be a viable option (Le
Gall and Tooker, 2017; Word et al., 2019). Practices that improve soil fertility, such as reducing grazing pressure in Inner Mongolia, China (Cease et al., 2012) or increasing soil organic matter and nitrogen on West African small-holder farms (Word et al., 2019) have the potential to alleviate locust problems. However, livestock and farm managers may not have the resources, knowledge, or incentives to implement practices to decrease locust populations. Therefore, cultural control options should be developed iteratively, in ways that integrate stakeholder perspectives, as well as the natural and social science (Cullen et al., 2017).

Such research linking land use to locust populations has revealed that this ecological feedback connects people across time and space producing both local and far-reaching environmental and social impacts (Cease et al., 2015), a process called telecoupling (Liu et al., 2013b; Kapsar et al., 2019). At a regional scale, locusts can spill from rangelands into croplands. For instance, the Australian plague locust is typically associated with grazing areas but during outbreaks will attack agricultural crops (Watts et al., 1982; Symmons, 1984; Wright and Symmons, 1987). Due to their powerful migratory capacity ( $>100 \mathrm{~km}$ traveled per day), locusts can link distant regions as well. Decisions about stocking rates in one region, for example, have the potential to initiate outbreaks that could lead to swarms invading distant regions. In addition to ecological links, distant regions are coupled through the economy (e.g., livestock markets) and policies. Indeed, because locusts connect distant regions and span continents, a major challenge is implementing consistent management efforts across broad regions (Cressman, 2016; Zhang et al., 2019). This requires many countries to work together from the level of the producer to national and international government organizations (Lockwood et al., 2001; Cease et al., 2015). This review highlights that humans are not passive players in their relationship with locusts. To effectively integrate land-use into management programs, important data on locust biology, such as nutritional preference and thermobiology, remain to be collected, particularly for non-model locust species, for which the expressions of density-dependent phase polyphenism in not well-understood (Song, 2011). In addition, this biology research needs to be linked to broader landscape patterns and their management, including producer decisions as well as market and government constraints.

\section{AUTHOR CONTRIBUTIONS}

ML wrote the discussion and sections for nine species and oversaw paper cohesion. RO performed the initial literature review and wrote the method section and sections for seven species. AC conceptualized the framework for the paper, wrote the introduction and sections for three species and edited all sections for consistency. All authors participated in revisions of the whole manuscript.

\section{FUNDING}

This work was supported by the National Science Foundation, United States [DEB-1313693 to AC]. 


\section{REFERENCES}

Abou-Ali, H., and Belhaj, M. (2008). "Cost benefit analysis of desert locusts' control: a multicountry perspective," in Economic Research Forum Working Papers. (Giza)

Abushama, F. T. (1970). Loss of water from the grasshopper Poecilocerus hieroglyphicus (Klug), compared with the tree locust Anacridium melanorhodon melanorhodon (Walker). Zeitschrift Angew. Entomol. 66, 160-167.

AgroAtlas - Pests - Aeropus sibiricus (L). - Siberian locust (Siberian grasshopper). (2003). Available online at: http://www.agroatlas.ru/en/content/pests/ Aeropus_sibiricus/index.html (accessed April 15, 2019).

Amatobi, C. I., Apeji, S. A., and Oyidi, O. (1988). Effects of farming practices on populations of two grasshopper pests (Kraussaria angulifra Krauss and Oedaleus senegalensis Krauss (Orthoptera: Acrididae) in Northern Nigeria. Int. J. Pest Manag. 34, 173-179. doi: 10.1080/09670878809371237

Anstey, M. L., Rogers, S. M., Ott, S. R., Burrows, M., and Simpson, S. J. (2009). Serotonin mediates behavioral gregarization underlying swarm formation in desert locusts. Science 323, 627-630. doi: 10.1126/science.1165939

Axelsen, J. A. (2009). Simulation studies of Senegalese Grasshopper ecosystem interactions I: the ecosystem model. Int. J. Pest Manag. 55, 85-97. doi: 10.1080/09670870802601084

Babah, M. A. O., and Sword, G. A. (2004). Linking locust gregarization to local resource distribution patterns across a large spatial scale. Environ. Entomol. 33, 1577-1583. doi: 10.1603/0046-225X-33.6.1577

Bahana, J. W. (2000). "The role of the international Red Locust Control Organisation for Central and Southern Africa (IRLCOCSA) in the management of migratory pests," in Workshop on Research Priorities for Migrant Pests of Agriculture in Southern Africa, Plant Protection Research Institute, Pretoria, South Africa, March 1999 (Chatham: Natural Resources Institute), 25-33.

Bal, A. B., Ouambama, Z., Moumouni, A., Dieng, I., Maiga, I. H., Gagare, S., et al. (2015). A simple tentative model of the losses caused by the Senegalese grasshopper, Oedaleus senegalensis (Krauss 1877) to millet in the Sahel. Int. J. Pest Manag. 61, 198-203. doi: 10.1080/09670874.2015.1031201

Balança, G., and De Visscher, M.-N. (1997). Impacts on nontarget insects of a new insecticide compound used against the desert locust Schistocerca gregaria (Forskal 1775). Arch. Environ. Contamin. Toxicol. 32, 58-62. doi: 10.1007/s002449900155

Barrera, M., and Turk, S. (1983). Estado actual de la langosta Schistocera cancellata paranensis (Burm.) en la Republica Argentina: neuvos aportes a su bioecologia. Acta Zool. Lilloana 27, 15-29.

Barrientos Lozano, L., Astacio Cabrera, O., Alvarez Bonilla, F., and Poot Martínez, O. (1992). Manual técnico sobre la langosta voladora (Schistocerca piceifrons piceifrons Walker, 1870) y otros Acridoideos de Centro América y Sureste de México. FAO, San Salvador (El Salvador) OIRSA, San Salvador (El Salvador).

Batáry, P., Orci, K. M., Báldi, A., Kleijn, D., Kisbenedek, T., and Erdos, S. (2007). Effects of local and landscape scale and cattle grazing intensity on Orthoptera assemblages of the Hungarian Great Plain. Basic Appl. Ecol. 8, 280-290. doi: 10.1016/j.baae.2006.03.012

Batten, A. (1969). The Senegalese grasshopper Oedaleus senegalensis Krauss. J. Appl. Ecol. 6, 27-45.

Beavan, K. (2017). Grasshoppers descend on Central Australia after heavy rainfall. ABC Rural. Available online at: https://www.abc.net.au/news/rural/201701-24/grasshoppers-swarm- outback-australia/8204992 (accessed February 28, 2019).

Behmer, S. T., Raubenheimer, D., and Simpson, S. J. (2001). Frequency-dependent food selection in locusts: a geometric analysis of the role of nutrient balancing. Anim. Behav. 61, 995-1005. doi: 10.1006/anbe.2000.1695

Bei-Bienko, G. Y., and Mishchenko, L. L. (1951). Acridoidea of the USSR and Adjacent Countries. Part II. Acridoidea of the USSR and adjacent countries.

Belayneh, Y. T. (2005). Acridid pest management in the developing world: a challenge to the rural population, a dilemma to the international community. $J$. Orthopt. Res. 14, 187-196. doi: 10.1665/1082-6467(2005)14[187:APMITD]2.0. $\mathrm{CO} ; 2$

Belovsky, G. E. (2000). "Do grasshoppers diminish grassland productivity? A new perspective for control based on conservation," in Grasshoppers and Grassland Health, NATO Science Series (Series 2.Environment Security), Vol 73, eds J. A. Lockwood, A. V. Latchininsky, and M. G. Sergeev (Dordrecht: Springer), 7-29. doi: 10.1007/978-94-011-4337-0_2
Belovsky, G. E., and Slade, J. B. (2000). Insect herbivory accelerates nutrient cycling and increases plant production. Proc. Natl. Acad. Sci. U.S.A. 97, 14412-14417. doi: 10.1073/pnas.250483797

Benfekih, L., Chara, B., and Doumandji-Mitiche, B. (2002). Influence of Anthropogenic Impact on the Habitats and Swarming Risks of Dociostaurus maroccanus and Locusta migratoria (Orthoptera, Acrididae) in the Algerian Sahara and the Semiarid Zone. J. Orthopt. Res. 11, 243-250. doi: 10.1665/10826467(2002)011[0243:IOAIOT]2.0.CO;2

Benfekih, L., and Petit, D. (2010). The annual cycle of Saharan populations of Locusta migratoria cinerascens (Orthoptera: Acrididae: Oedipodinae) in Algeria. Ann. Soc. Entomol. France 46, 351-358. doi: 10.1080/00379271.2010.10697674

Bernardi, M. (1986). Le Problème des sauteriaux. Compte Rendu du Séminaire International du Projet CILSS de Lutte Intégrée, Niamey, Niger. 6-13 décembre 1984, 43-57.

Bernays, E. A., Chamberlain, D. J., and Woodhead, S. (1983). Phenols as nutrients for a phytophagous insect Anacridium melanorhodon. J. Insect Physiol. 29, 535-539. doi: 10.1016/0022-1910(83)90085-9

Bernays, E. A., and Chapman, R. F. (1973). The role of food plants in the survival and development of Chortoicetes terminifera (Walker) under drought conditions. Austr. J. Zool. 21, 575-592. doi: 10.1071/ZO9730575

Bernays, E. A., and Hamai, J. (1987). Head size and shape in relation to grass feeding in Acridoidea (Orthoptera). Int. J. Insect Morphol. Embryol. 16, 323-330. doi: 10.1016/0020-7322(87)90004-3

Bernays, E. A., and Woodhead, S. (1982). Incorporation of dietary phenols into the cuticle in the tree locust Anacridium melanorhodon. J. Insect Physiol. 28, 601-606. doi: 10.1016/0022-1910(82)90057-9

Botha, R.oss, and van Ark, P. (1974). Residues in sheep exposed to BHC treated Karoo-veld in the outbreak region of the brown locust Locustana pardalina (Walker). Phytophylactica 6, 235-248.

Bouaïchi, A. (1996). The behavioural and environmental bases of gregarization in the desert locust Schistocerca gregaria (Forskal). (Ph D. Thesis), University of Oxford.

Bouchard, J. (1998). Évaluation de l'impact de produits toxiques sur le criquet de montagne Gomphocerus sibiricus (colchicine et 6-mercaptopurine). Ann. Sci. Nat. 19, 127-140. doi: 10.1016/S0003-4339(99)80002-1

Brader, L., Djibo, H., Faye, F. G., Ghaout, S., Lazar, M., Luzietoso, P. N., et al. (2006). Towards a More Effective Response to Desert Locusts and Their Impacts on Food Security, Livelihoods and Poverty. Multilateral Evaluation of the 2003-05 Desert Locust Campaign. Food and Agriculture Organisation, Rome.

Branson, D. H., Joern, A., and Sword, G. A. (2006). Sustainable management of insect herbivores in grassland ecosystems: new perspectives in grasshopper control. Bio Sci. 56, 743-755. doi: 10.1641/0006-3568(2006)56[743:SMOIHI]2. $0 . \mathrm{CO} ; 2$

Bredo, H. J. (1963). Rapport de mission relatif a l'etude du Schistocerca paranensis Burm. en Amerique Centrale, Panama et Mexique. 77. Rome, FAO.

Breman, H., and Kessler, J. J. (1997). The potential benefits of agroforestry in the Sahel and other semi-arid regions. Eur. J. Agron. 7, 25-33. doi: 10.1016/S1161-0301(97)00035-X

Bughio, B. A., Sultana, R., RIND, M., and Wagan, M. S. (2014). Some studies on the taxonomic status of the genus Aiolopus Fieber (Acrididae: Acridoidea: Orthoptera) from Pakistan. J. Biodiv. Environ. Sci 4, 410-417.

Bullen, F. T. (1966). Locusts and grasshoppers as pests of crops and pasture-a preliminary economic approach. J. Appl. Ecol. 147-168. doi: 10.2307/2401671

Bullen, F. T. (1968). Report on an Outbreak of the Spur-Throated Locust (Austracris Guttulosa Walk.) in the East Kimberley Region of Western Australia. CSIRO Division of Entomology.

Burnett, G. F. (1951). Field Observations on the Behaviour of the Red Locust (Nomadacris Septemfasciata Serville) in the Solitary Phase. Available online at: https://www.cabdirect.org/cabdirect/abstract/19510500702 (accessed March 12, 2018).

Casimir, M., and Edge, V. E. (1979). The Development and Impact of a Control Campaign against Austracris guttulosa in New South Wales. Proc. Acad. Natl. Sci. U.S.A. 25, 223-236. doi: 10.1080/09670877909412089

Cease, A. (2012). Locust Outbreaks and Migration in the Asian Steppe: The Influence of Land Management Practices and Host Plant Nutrient Status. Available online at: https://search.proquest.com/docview/1012769819/ abstract/9493761F6ECC4FBFPQ/1 (accessed September 3, 2018). 
Cease, A. J., Elser, J. J., Fenichel, E. P., Hadrich, J. C., Harrison, J. F., and Robinson, B. E. (2015). Living with locusts: connecting soil nitrogen, locust outbreaks, livelihoods, and livestock markets. Bio Sci. 65, 551-558. doi: 10.1093/biosci/biv048

Cease, A. J., Elser, J. J., Ford, C. F., Hao, S., Kang, L., and Harrison, J. F. (2012). Heavy livestock grazing promotes locust outbreaks by lowering plant nitrogen content. Science 335, 467-469. doi: 10.1126/science.1214433

Cease, A. J., Hao, S., Kang, L., Elser, J. J., and Harrison, J. F. (2010). Are color or high rearing density related to migratory polyphenism in the band-winged grasshopper, Oedaleus asiaticus? J. Insect Physiol. 56, 926-936. doi: 10.1016/j.jinsphys.2010.05.020

Cease, A. J., Harrison, J. F., Hao, S., Niren, D. C., Zhang, G., Kang, L., et al. (2017). Nutritional imbalance suppresses migratory phenotypes of the Mongolian locust (Oedaleus asiaticus). R. Soc. Open Sci. 4:161039. doi: 10.1098/rsos.161039

Chambers, P. G., Simpson, S. J., and Raubenheimer, D. (1995). Behavioural mechanisms of nutrient balancing in Locusta migratoria nymphs. Anim. Behav. 50, 1513-1523. doi: 10.1016/0003-3472(95)80007-7

Chandra, S., and Williams, G. (1983). Frequency-dependent selection in the grazing behaviour of the desert locust Schistocerca gregaria. Ecol. Entomol. 8, 13-21. doi: 10.1111/j.1365-2311.1983.tb00477.x

Chapman, R. F. (1959). Observations on the flight activity of the red locust, Nomadacris Septemfasciata (Serville). Behaviour 14, 300-333. doi: 10.1163/156853959X00126

Chapman, R. F. (1976). A Biology of Locusts. Available online at: https://www. cabdirect.org/cabdirect/abstract/19760541473 (accessed February 20, 2018).

Chapuis, M.-P., Popple, J.-A. M., Berthier, K., Simpson, S. J., Deveson, E., Spurgin, P., et al. (2011). Challenges to assessing connectivity between massive populations of the Australian plague locust. Proc. R. Soc. B: Biol. Sci. 278, 3152-3160. doi: 10.1098/rspb.2010.2605

Chapuis, M. P., Foucart, A., Plantamp, C., Blondin, L., Leménager, N., Benoit, L., et al. (2017). Genetic and morphological variation in non-polyphenic southern African populations of the desert locust. Afr. Entomol. 25, 13-24. doi: $10.4001 / 003.025 .0013$

Cheke, R. A. (1990). A migrant pest in the Sahel: the Senegalese grasshopper Oedaleus senegalensis. Phil. Trans. R. Soc. Lond. B 328, 539-553. doi: $10.1098 /$ rstb.1990.0126

Chen, H. H., and Kang, L. (2000). Olfactory responses of two species of grasshoppers to plant odours. Entomol. Exp. Applic. 95, 129-134. doi: $10.1046 /$ j.1570-7458.2000.00650.x

China Ministry of Agriculture (2012). National Rangeland Monitoring Report 2011 (in Chinese). Beijing, China: China Ministry of Agriculture.

Cigliano, M. M., Braun, H., Eades, D. C., and Otte, D. (2017). Orthoptera Species File. Version 5.0/5.0.

Cisse, S., Ghaout, S., Mazih, A., Babah Ebbe, M. A. O., Benahi, A. S., and Piou, C. (2013). Effect of vegetation on density thresholds of adult desert locust gregarization from survey data in Mauritania. Entomol. Exp. Applic. 149, 159-165. doi: 10.1111/eea.12121

Cisse, S., Ghaout, S., Mazih, A., Ould Babah Ebbe, M. A., and Piou, C. (2015). Estimation of density threshold of gregarization of desert locust hoppers from field sampling in Mauritania. Entomol. Exp. Appl. 156, 136-148. doi: $10.1111 /$ eea.12323

Clark, D. P. (1965). On the sexual maturation, breeding, and oviposition behaviour of the Australian plague locust, Chortoicetes terminifera (Walk.). Austr. J. Zool. 13, 17-46. doi: 10.1071/ZO9650017

Clark, L. R. (1947). An Ecological Study of the Australian Plague Locust (Chortoicetes terminifera Walk.) in the Bogan-Macquarie Outbreak Area. NSW.

Clark, L. R. (1950). On the abundance of the Australian Plague Locust Chortoicetes terminifera (Walker) in relation to the presence of trees. Austr. J. Agric. Res. 1, 64-75. doi: 10.1071/AR9500064

Clark, X., Clissold, F. J., Charleston, M. A., and Simpson, S. J. (2013). "Foraging in a nutritionally complex world: tests using agent-based models and locusts," (Oxford Univ Press Inc Journals Dept, 2001 EVANS RD, CARY, NC 27513 USA), E266-E266.

Clissold, F. J., Sanson, G. D., and Read, J. (2006). The paradoxical effects of nutrient ratios and supply rates on an outbreaking insect herbivore, the Australian plague locust. J. Anim. Ecol. 75, 1000-1013. doi: 10.1111/j.1365-2656.2006.01122.x
Collett, M., Despland, E., Simpson, S. J., and Krakauer, D. C. (1998). Spatial scales of desert locust gregarization. Proc. Natl Acad. Sci. U.S.A. 95, 13052-13055. doi: $10.1073 /$ pnas.95.22.13052

COPR (1982). The Locust and Grasshopper Agricultural Manual. London: Overseas Pest Research. 690.

Cressman, K. (2013). Role of remote sensing in desert locust early warning. J. Appl. Remote Sens. 7:075098. doi: 10.1117/1.JRS.7.075098

Cressman, K. (2016). Desert locust. Biol. Environ. Hazards Risks Disasters 87-105. doi: 10.1016/B978-0-12-394847-2.00006-1

Crooks, W. T., and Cheke, R. A. (2014). Soil moisture assessments for brown locust Locustana pardalina breeding potential using synthetic aperture radar. JARS 8:084898. doi: $10.1117 / 1$.JRS.8.084898

Cullen, D. A., Cease, A. J., Latchininsky, A. V., Ayali, A., Berry, K., Buhl, J., et al. (2017). "From molecules to management: mechanisms and consequences of locust phase polyphenism," in Advances in Insect Physiology, ed H. Verlinden (Oxford: Elsevier), 167-285. doi: 10.1016/bs.aiip.2017.06.002

Cullen, D. A., Sword, G. A., Dodgson, T., and Simpson, S. J. (2010). Behavioural phase change in the Australian plague locust, Chortoicetes terminifera, is triggered by tactile stimulation of the antennae. J. Insect Physiol. 56, 937-942. doi: 10.1016/j.jinsphys.2010.04.023

Cullen, D. A., Sword, G. A., and Simpson, S. J. (2012). Optimizing multivariate behavioural syndrome models in locusts using automated video tracking. Anim. Behav. 84, 771-784. doi: 10.1016/j.anbehav.2012.06.031

D’Alessandro, S., Fall, A. A., Grey, G., Simpkin, S., and Wane, A. (2015). Senegal. Washington, DC: Agricultural sector risk assessment.

De Villiers, W. M. (1988). On the plague dynamics of the brown locust Locustana pardalina (Walk.), in Proceedings of the Locust Symposium (Johannesburg: Bulletin of the South African Institute of Ecologists), 41-49.

De Vreyer, P., Guilbert, N., and Mesple-Somps, S. (2014). Impact of natural disasters on education outcomes: evidence from the 1987-89 locust plague in Mali. J. Afr. Econ. 24, 57-100. doi: 10.1093/jae/eju018

Despland, E. (2005). Diet breadth and anti-predator strategies in desert locusts and other Orthopterans. Orth 14, 227-233. doi: 10.1665/10826467(2005)14[227:DBAASI]2.0.CO;2

Despland, E., Collett, M., and Simpson, S. J. (2000). Small-scale processes in desert locust swarm formation: how vegetation patterns influence gregarization. Oikos 88, 652-662. doi: 10.1034/j.1600-0706.2000.880322.x

Despland, E., Rosenberg, J., and Simpson, S. J. (2004). Landscape structure and locust swarming: a satellite's eye view. Ecography 27, 381-391. doi: 10.1111/j.0906-7590.2004.03779.x

Despland, E., and Simpson, S. J. (2000). Small-scale vegetation patterns in the parental environment influence the phase state of hatchlings of the desert locust. Physiol. Entomol. 25, 74-81. doi: 10.1046/j.1365-3032.2000.00166.x

Despland, E., and Simpson, S. J. (2005a). Food choices of solitarious and gregarious locusts reflect cryptic and aposematic antipredator strategies. Anim. Behav. 69, 471-479. doi: 10.1016/j.anbehav.2004.04.018

Despland, E., and Simpson, S. J. (2005b). Surviving the change to warning colouration: density-dependent polyphenism suggests a route for the evolution of aposematism. Chemoecology 15, 69-75. doi: 10.1007/s00049-005-0296-6

Deveson, E. D. (2011). The search for a solution to Australian locust outbreaks: how developments in ecology and government responses influenced scientific research. Hist. Records Austr. Sci. 22, 1-31. doi: 10.1071/HR11003

Deveson, E. D. (2012). Naturae amator and the grasshopper infestations of South Australia's early years. Transact. R. Soc. South Austr. 136, 1-15. doi: $10.1080 / 03721426.2012 .10887158$

Deveson, E. D., and Walker, P. W. (2005). Not a one-way trip: historical distribution data for Australian plague locusts support frequent seasonal exchange migrations. J. Orthopt. Res. 14, 91-106. doi: 10.1665/10826467(2005)14[91:NAOTHD]2.0.CO;2

DPI (2018). Spur-Throated Locust. Department of Primary Industries and Regional Development. Available online at: https://www.agric.wa.gov.au/pest-insects/ spur-throated-locust?nopaging=1 (accessed March 1, 2019).

DPI (2019). Yellow-winged locusts. Department of Primary Industries and Regional Development. Available online at: https://www.agric.wa.gov.au/ pasture-management/yellow-winged-locusts (accessed February 28, 2019).

Drake, V. A., and Farrow, R. A. (1983). The nocturnal migration of the Australian plague locust, Chortoicetes terminifera (Walker) (Orthoptera: Acrididae): 
quantitative radar observations of a series of northward flights. Bull. Entomol. Res. 73, 567-585. doi: 10.1017/S0007485300009172

Duranton, J.-F., Monard, A., and Morales, R. S. (2006). Contribution à l'étude de la bio-écologie de deux locustes péruviens, Schistocerca cf. interrita Scudder 1899 et Schistocerca piceifrons peruviana Lynch Arribalzaga 1903 (Orthoptera, Cyrtacanthacridinae). J. Orthopt. Res. 157-169. doi: 10.1665/10826467(2006)15[157:CLDLBD]2.0.CO;2

Duranton, J.-F., Monard, A., and Solano, R. (2001). Outbreaks of Schistocerca interrita (Scudder, 1899) in Northern Peru. Metaleptea.

Elamin, A. E., Abdalla, A. M., and El Naim, A. M. (2013). Studies on population dynamics of senegalese grasshopper (Oedaleus senegalensis) in Kordofan of Sudan. World 1, 85-89.

Elamin, H. M. A., Roth, M., and Taha, M. E. (2008). "The consequences of defoliation of gum arabic tree (Acacia senegal) by Sahelian tree locust (Anacridium melanorhodon melanorhodon) for the gum producers in North Kordofan State, Sudan," in Conference on International Research On Food Security, Natural Resource Management and Rural Development (Stuttgart: University of Hohenheim), 7-9.

Ellis, P. E., and Ashall, C. (1957). Field studies on diurnal behaviour, movement and aggregation in the desert locust (Schistocerca gregaria Forskål). Anti-locust Bull. 25, 4-94.

El-Mallakh, O. S., and El-Mallakh, R. S. (1994). Insects of the Qur'an. Am. Entomol. 40, 82-84. doi: 10.1093/ae/40.2.82

Evans, C. S., and Bell, E. A. (1979). Non-protein amino acids of Acacia species and their effect on the feeding of the acridids Anacridium melanorhodon and Locusta migratoria. Phytochemistry 18, 1807-1810. doi,: 10.1016/00319422(79)83057-5

FAO, News Article: Red Locust Disaster in Eastern Africa Prevented (2009). Available online at: http://www.fao.org/news/story/en/item/21084/icode/ (accessed March 12, 2018).

Farrow, R. A. (1979). Causes of Recent Changes in the Distribution and Abundance of the Migratory Locust (Locusta migratoria L.) in Australia in Relation to Plagues. Report. CSIRO Division of Entymology, 32-41.

Farrow, R. A. (1979a). Causes of Recent Changes in the Distribution and Abundance of the Migratory Locust (Locusta migratoria L.) in Australia in Relation to Plagues.

Farrow, R. A. (1979b). Population Dynamics of the Australian Plague Locust, Chortoicetes terminifera (Walker), in Central Western New South Wales. I. Reproduction and Migration in Relation to Weather. Austr. J. Zool. 27, 717-745. doi: 10.1071/ZO9790717

Farrow, R. A. (1987). Effects of changing land use on outbreaks of tropical migratory locust, Locusta migratoria migratorioides (R. and F.). Int. J. Trop. Insect Sci. 8, 969-975. doi: 10.1017/S1742758400023262

Feng, G. H., Fan, S. X., Liu, Q. F., Yang, Y. B., Ma, L. X., and Cao, G. S. (1994). The determination capacity for eaten of several species grasshoppers in grassland in outside cage condition. Acta Agrestia Sinica 3, 230-235.

Fisker, E. N., Bak, J., and Niassy, A. (2007). A simulation model to evaluate control strategies for the grasshopper Oedaleus senegalensis in West Africa. Crop Protect. 26, 592-601. doi: 10.1016/j.cropro.2006.04.026

Flores Granados, F. (2011). Las plagas de langosta en el área maya: ambiente e historia de una calamidad en la época prehispánica. Península $6,27-46$

Gartry, L., and Edwards, T. (2016). Summer rain brings locust swarms to Kimberley. ABC News. Available online at: https://www.abc.net.au/news/201603-24/locusts-swarm-kimberley-town-halls-creek-pastoral-stations/7276048 (accessed February 28, 2019).

Gastón, J. (1969). Sintesis Historica de la Langosta en la Argentina. Secretaría de Estado de Agricultura y Ganadería.

Ghadraoui, L. E., Petit, D., Picaud, F., and Yamani, J. E. (2002). Relationship between labrum sensilla number in the Moroccan locust Dociostaurus maroccanus and the nature of its diet. J. Orthopt. Res. 11, 11-18. doi: 10.1665/ 1082-6467(2002)011[0011:RBLSNI]2.0.CO;2

Gibson, D. J. (2009). Grasses and Grassland Ecology. Oxford: Oxford University Press.

Giese, M., Brueck, H., Gao, Y. Z., Lin, S., Steffens, M., Kögel-Knabner, I., et al. (2013). N balance and cycling of Inner Mongolia typical steppe: a comprehensive case study of grazing effects. Ecol. Monogr. 83, 195-219. doi: $10.1890 / 12-0114.1$
Gosálvez, J., and López-Fernández, C. (1981). Extra heterochromatin in natural populations of Gomphocerus sibiricus (Orthoptera: Acrididae). Genetica 56, 197-204. doi: 10.1007/BF00057560

Graham, R. I., Deacutis, J. M., Pulpitel, T., Ponton, F., Simpson, S. J., and Wilson, K. (2014). Locusts increase carbohydrate consumption to protect against a fungal biopesticide. J. Insect Physiol. 69, 27-34. doi: 10.1016/j.jinsphys.2014. 05.015

Graham, R. I., Deacutis, J. M., Simpson, S. J., and Wilson, K. (2015). Body condition constrains immune function in field populations of female Australian plague locust Chortoicetes terminifera. Parasite Immunol. 37, 233-241. doi: 10.1111/pim.12179

Gray, L. J., Sword, G. A., Anstey, M. L., Clissold, F. J., and Simpson, S. J. (2009). Behavioural phase polyphenism in the Australian plague locust (Chortoicetes terminifera). Biol. Lett. 5, 306-309. doi: 10.1098/rsbl.2008.0764

Gueguen-Genest, M. C., and Gueguen, A. (1987). Effect of sheep grazing on population dynamic of the Siberian criquet Gomphocerus sibericus Finot Orthoptera Acrididae in an alpine grassland. Comptes Rendus Acad. Sci. Ser. 3 Sci. Vie 304, 443-447.

Guo, K. U. N., HAO, S.-G., Sun, O. J., and Kang, L. E. (2009). Differential responses to warming and increased precipitation among three contrasting grasshopper species. Glob. Change Biol. 15, 2539-2548. doi: 10.1111/j.1365-2486.2009.01861.x

Guo, W., Wang, X., Ma, Z., Xue, L., Han, J., Yu, D., et al. (2011). CSP and takeout genes modulate the switch between attraction and repulsion during behavioral phase change in the migratory locust. PLoS Genet. 7:e1001291. doi: 10.1371/journal.pgen.1001291

Han, J. G., Zhang, Y. J., Wang, C. J., Bai, W. M., Wang, Y. R., Han, G. D., et al. (2008). Rangeland degradation and restoration management in China. Rangeland J. 30, 233-239. doi: 10.1071/RJ08009

Hanboonsong, Y., Jamjanya, T., and Durst, T. B. (2013). Six-Legged Livestock: Edible Insect Farming, Collection and Marketing in Thailand. Bangkok: Food and Agriculture Organization of the United Nations, Regional Office for Asia and the Pacific.

Hao, S., Wang, S., Cease, A., and Kang, L. (2015). Landscape level patterns of grasshopper communities in Inner Mongolia: interactive effects of livestock grazing and a precipitation gradient. Landsc. Ecol. 30, 1657-1668. doi: 10.1007/s10980-015-0247-8

Hao, S.-G., and Kang, L. (2004). Postdiapause development and hatching rate of three grasshopper species (Orthoptera: Acrididae) in Inner Mongolia. Environ. Entomol. 33, 1528-1534. doi: 10.1603/0046-225X-33.6.1528

Haroon, W. M., Pages, C., Vassal, J.-M., Abdalla, A. M., Luong-Skovmand, M., and Lecoq, M. (2011). Laboratory and field investigation of a mixture of Metarhizium acridum and Neem seed oil against the Tree Locust Anacridium melanorhodon melanorhodon (Orthoptera: Acrididae). Biocontrol Sci. Technol. 21, 353-366. doi: 10.1080/09583157.2010.550678

Harvey, A. W. (1983). Schistocerca piceifrons (Walker)(Orthoptera: Acrididae), the swarming locust of tropical America: a review. Bull. Entomol. Res. 73, 171-184. doi: 10.1017/S0007485300008786

Hernández-Zul, M. I., Quijano-Carranza, J. A., Yáñez-López, R., OcampoVelázquez, R. V., Torres-Pacheco, I., Guevara-González, R. G., et al. (2013). Dynamic simulation model of central American locust Schistocerca piceifrons (Orthoptera: Acrididae). Florida Entomol. 96, 1274-1283. doi: 10.1653/024.096.0405

Hoekstra, J. M., Boucher, T. M., Ricketts, T. H., and Roberts, C. (2005). Confronting a biome crisis: global disparities of habitat loss and protection. Ecol. Lett. 8, 23-29. doi: 10.1111/j.1461-0248.2004.00686.x

Holt, J., and Colvin, J. (1997). A differential equation model of the interaction between the migration of the Senegalese grasshopper, Oedaleus senegalensis, its predators, and a seasonal habitat. Ecol. Modell. 101, 185-193. doi: 10.1016/S0304-3800(97)01981-9

Hooper, G. H. S. (1998). The changing environment of locust control in Australia. J. Orthopt. Res. 113-115. doi: 10.2307/3503505

Houndekon, V. A., and De Groote, H. (1998). "Health costs and externalities of pesticide use in locust and grasshopper control in the Sahel," in Annual conference of the American Agricultural Economics Association (Milwaukee, WI).

Huang, X., McNeill, M., and Zhang, Z. (2015). Quantitative analysis of plant consumption and preference by Oedaleus asiaticus (Acrididae: Oedipodinae) in 
changed plant communities consisting of three grass species. Environ. Entomol. 45, 163-170. doi: 10.1093/ee/nvv172

Huang, X., McNeill, M. R., Ma, J., Qin, X., Tu, X., Cao, G., et al. (2017b). Gut transcriptome analysis shows different food utilization efficiency by the grasshopper Oedaleus asiaticus (Orthoptera: Acrididae). J. Econ. Entomol. 110, 1831-1840. doi: 10.1093/jee/tox128

Huang, X., Wu, H., McNeill, M. R., Qin, X., Ma, J., Tu, X., et al. (2016). Quantitative analysis of diet structure by real-time PCR, reveals different feeding patterns by two dominant grasshopper species. Sci. Rep. 6:32166. doi: 10.1038/srep32166

Huang, X. B., McNeill, M. R., Ma, J. C., Qin, X. H., Tu, X. B., Cao, G. C., et al. (2017a). Biological and ecological evidences suggest Stipa krylovii (Pooideae), contributes to optimal growth performance and population distribution of the grasshopper Oedaleus asiaticus. Bull. Entomol. Res. 107, 401-409. doi: $10.1017 /$ S000748531600105X

Hunter, D. M. (1982). Adult development in the Australian plague locust, Chortoicetes terminifera (Walker)(Orthoptera: Acrididae). Bull. Entomol. Res. 72, 589-598. doi: 10.1017/S0007485300008622

Hunter, D. M. (1989). The response of Mitchell grasses (Astrebla spp.) and Button grass (Dactyloctenium radulans (R. Br.)) to rainfall and their importance to the survival of the Australian plague locust, Chortoicetes terminifera (Walker), in the arid zone. Austr. J. Ecol. 14, 467-471, doi: 10.1111/j.1442-9993.1989.tb01456.x

Hunter, D. M. (2004). Advances in the control of locusts (Orthoptera: Acrididae) in eastern Australia: from crop protection to preventive control. Austr. J. Entomol. 43, 293-303. doi: 10.1111/j.1326-6756.2004.00433.x

Hunter, D. M., and Cosenzo, E. L. (1990). The origin of plagues and recent outbreaks of the South American locust, Schistocerca cancellata (Orthoptera: Acrididae) in Argentina. Bull. Entomol. Res. 80, 295-300. doi: $10.1017 /$ S0007485300050495

Hunter, D. M., McCulloch, L., and Wright, D. E. (1981). Lipid accumulation and migratory flight in the Australian plague locust, Chortoicetes terminifera (Walker)(Orthoptera: Acrididae). Bull. Entomol. Res. 71, 543-546. doi: $10.1017 /$ S0007485300010051

Hunter, D. M., Milner, R. J., and Spurgin, P. A. (2001). Aerial treatment of the Australian plague locust, Chortoicetes terminifera (Orthoptera: Acrididae) with Metarhizium anisopliae (Deuteromycotina: Hyphomycetes). Bull. Entomol. Res. 91, 93-99.

Hunter-Jones, P. (1967). Life history of the Central American Locust, Schistocerca sp.(Orthoptera: Acrididae), in the laboratory. Ann. Entomol. Soc. Am. 60, 468-477. doi: 10.1093/aesa/60.2.468

Il'enko, M. I. (1930). The Development and Meta-Morphoses of the Siberian Grasshopper Gomphocerus sibiricus. The Development and Meta-morphoses of the Siberian Grasshopper Gomphocerus sibiricus. Available online at: https:// www.cabdirect.org/cabdirect/abstract/19310500191 (accessed April 27, 2018).

Jenkins, C. F. H. (1968). Grasshoppers and locusts in Western Australia. J. Depart. Agric. West. Austr. Ser. 4 9, 169-175.

Jiang, X., Maimaitiming, Zhang, L. (2003). Nocturnal Migration of Grasshopper (Acrididae: Oedaleus asiaticus). Acta Agrest. Sin. 1, 75-77.

Jie, C., Jing-Zhang, C., Man-Zhi, T., and Zi-Tong, G. (2002). Soil degradation: a global problem endangering sustainable development. J. Geogr. Sci. 12, 243-252. doi: 10.1007/BF02837480

Joern, A. (1986). Experimental study of avian predation on coexisting grasshopper populations (Orthoptera: Acrididae) in a Sandhills Grassland. Oikos 46, 243-249. doi: $10.2307 / 3565473$

Joern, A. (2000). "What are the consequences of non-linear ecological interactions for grasshopper control strategies?," in Grasshoppers and Grassland Health, eds J. Lockwood, A. Latchininsky, and M. G. Sergeev (New York, NY: Springer), 131-144. doi: 10.1007/978-94-011-4337-0_9

Joyce, R. J. V. (1952). The Ecology of Grasshoppers in east central Sudan. The Ecology of Grasshoppers in east central Sudan. Available online at: https://www. cabdirect.org/cabdirect/abstract/19520500484 (accessed February 22, 2018).

Jutsum, A. R., and Goldsworthy, G. J. (1976). Fuels for flight in Locusta. J. Insect Physiol. 22, 243-249. doi: 10.1016/0022-1910(76) 90032-9

Kang, L., Chen, X., Zhou, Y., Liu, B., Zheng, W., Li, R., et al. (2004). The analysis of large-scale gene expression correlated to the phase changes of the migratory locust. Proc. Natl. Acad. Sci. U.S.A. 101, 17611-17615. doi: $10.1073 /$ pnas. 0407753101
Kang, L., and Chen, Y. (1995). Dynamics of grasshopper communities under different grazing intensities in Inner Mongolian steppes. Insect Sci. 2, 265-281. doi: 10.1111/j.1744-7917.1995.tb00048.x

Kang, L., Han, X., Zhang, Z., and Sun, O. J. (2007). Grassland ecosystems in China: review of current knowledge and research advancement. Philos. Trans. R. Soc. B Biol. Sci. 362, 997-1008. doi: 10.1098/rstb.2007.2029

Kapsar, K. E., Hovis, C. L., Bicudo da Silva, R. F., Buchholtz, E. K., Carlson, A. K., Dou, Y., et al. (2019). Telecoupling Research: The First Five Years. Sustainability 11, 1033. doi: $10.3390 /$ su11041033

Kathy, C. (2006). Yellow winged locusts on the swarm in Qld. ABC Rural. Available online at: http://www.abc.net.au/site-archive/rural/content/2006/ s1590089.htm (accessed February 28, 2019).

Kaya, M., Erdogan, S., Mol, A., and Baran, T. (2015). Comparison of chitin structures isolated from seven Orthoptera species. Int. J. Biol. Macromol. 72, 797-805. doi: 10.1016/j.ijbiomac.2014.09.034

Keay-Bright, J., and Boardman, J. (2006). Changes in the distribution of degraded land over time in the central Karoo, South Africa. Catena 1, 1-14. doi: $10.1016 /$ j.catena.2005.12.003

Key, K. H. L. (1945). Council for Scientific and Industrial Research, 127 p., 8, no. 186, p. 119-122.

Kieser, M., Thackrah, A., and Rosenberg, J. (2010). Changes in the Outbreak Region of the Brown Locust in Southern Africa. Available online at: http://gadi.agric.za/ articles/Kieser_M/kieser_vol4_2002_locust.php (accessed May 1, 2019).

Köhler, P. (1962). Ecología de la zona central y de gregarización de la langosta en la República Argentina. Idia 7:108.

Latchininsky, A. V. (1998). Moroccan locust Dociostaurus maroccanus (Thunberg, 1815): a faunistic rarity or an important economic pest? J. Insect Conserv. $2,167-178$.

Latchininsky, A. V. (2013). Locusts and remote sensing: a review. JARS 7:075099. doi: 10.1117/1.JRS.7.075099

Latchininsky, A. V., and Launois Luong, M. H. (1992). Le Criquet Marocain, Dociostaurus maroccanus (Thunberg, 1815), Dans la Partie Orientale de Son Aire de Distribution: Etude Monographique Relative a l'ex-URSS et Aux Pays Proches. Montpellier: CIRAD-PRIFAS, 289.

Launois, M. (1978). Modélisation Écologique et Simulation Opérationnelle en Acridologie: Application à Oedaleus senegalensis (Krauss, 1877). Paris: Ministère de la Coopéracion/GERDAT.

Launois, M. (1979). An ecological model for the study of the grasshopper Oedaleus senegalensis in West Africa. Phil. Trans. R. Soc. Lond. B 287, 345-355. doi: 10.1098/rstb.1979.0066

Le Gall, M., and Tooker, J. F. (2017). Developing ecologically based pest management programs for terrestrial molluscs in field and forage crops. J. Pest Sci. 90, 1-14. doi: 10.1007/s10340-017-0858-8

Lea, A. (1958a). Recent outbreaks of the brown locust, Locustana pardalina (Walk), with special reference to the influence of rainfall. J. Entomol. Soc. South. Afr. 21, 162-213.

Lea, A. (1958b). The continuing challenge of the brown locust. J. Entomol. Soc. South. Afr. 21, 03-15.

Lecoq, M., Chamouine, A., and Luong-Skovmand, M.-H. (2011). Phasedependent color polyphenism in field populations of red locust nymphs (Nomadacris septemfasciata Serv.) in Madagascar. Psyche. 2011:105352. doi: $10.1155 / 2011 / 105352$

Li, J., Li, S., Wang, D., and Ji, R. (2014). Changes in the contents of stress resistant substances in Gomphocerus sibiricus (Orthoptera: Acrididae) under high temperature stress. Acta Entomol. Sin. 57, 1155-1161.

Li, S., Huang, X., McNeill, M. R., Liu, W., Tu, X., Ma, J., et al. (2019). Dietary stress from plant secondary metabolites contributes to grasshopper (Oedaleus asiaticus) migration or plague by regulating insect insulin-like signaling pathway. Front. Physiol. 10:531. doi: 10.3389/fphys.2019.00531

Li, X. L., Yuan, Q. H., Wan, L. Q., and He, F. (2008). Perspectives on livestock production systems in China. Rangeland J. 30, 211-220. doi: 10.1071/RJ08011

Liu, G.-H., Hao, S.-G., Shao, X.-Q., Zhang, Y.-J., and Wang, S.-P. (2013a). Diet composition and trophic niche of Oedaleus asiaticus (Orthoptera: Acrididae) in natural grasslands under different grazlng pressure in Inner Mongolia, northern China. Acta Entomol. Sin. 56, 537-547.

Liu, J., Hull, V., Batistella, M., DeFries, R., Dietz, T., Fu, F., et al. (2013b). Framing sustainability in a telecoupled World. Ecol. Soc. 18:26. doi: 10.5751/ES-05873-180226 
Loaiza, P. A., Balocchi, O., and Bertrand, A. (2017). Carbohydrate and crude protein fractions in perennial ryegrass as affected by defoliation frequency and nitrogen application rate. Grass Forage Sci. 72, 556-567. doi: 10.1111/gfs.12258

Lockwood, J. A., and Debrey, L. D. (1990). A solution for the sudden and unexplained extinction of the rocky mountain grasshopper (Orthoptera: Acrididae). Environ. Entomol. 19, 1194-1205. doi: 10.1093/ee/19.5.1194

Lockwood, J. A., Showler, A. T., and Latchininsky, A. V. (2001). Can we make locust and grasshopper management sustainable? J. Orthoptera Res. 10, 315-329. doi: 10.1665/1082-6467(2001)010[0315:CWMLAG]2.0.CO;2

Locust Control Campaign in Northern Laos, | FAO in Laos | Food and Agriculture Organization of the United Nations (2016). Available online at: http://www.fao. org/laos/news/detail-events/en/c/414367/ (accessed April 15, 2019).

Long, W. H., and Hensley, S. D. (1972). Insect pests of sugar cane. Annu. Rev. Entomol. 17, 149-176. doi: 10.1146/annurev.en.17.010172.001053

Louveaux, A., Peyrelongue, J. Y., and Gillon, Y. (1988). Outbreaks of the Italian Locust (Calliptamus italicus (L.)) in Poitou-Charentes (France). Comptes Rendus de l'Academie d'Agriculture de France (France).

Loveridge, J. P., and Bursell, E. (1975). Studies on the water relations of adult locusts (Orthoptera, Acrididae). I. Respiration and the production of metabolic water. Bull. Entomol. Res. 65, 13-20. doi: 10.1017/S0007485300005708

Lynch Arribalzaga, E. (1903). La langosta voladora del Peru. An. Mus. Nac. Hist. Nat. B Aires 9, 1-5.

Lynch Arribalzaga, E. (1918). La langosta voladora de Colombia y Venezuela. Physis 4, 49-79.

Ma, C., Liu, C., Yang, P., and Kang, L. (2009). The complete mitochondrial genomes of two band-winged grasshoppers, Gastrimargus marmoratus and Oedaleus asiaticus. BMC Genomics 10:156. doi: 10.1186/1471-2164-10-156

Ma, C., Yang, P., Jiang, F., CHAPUIS, M.-P., Shali, Y., Sword, G. A., et al. (2012). Mitochondrial genomes reveal the global phylogeography and dispersal routes of the migratory locust. Mol. Ecol. 21, 4344-4358. doi: 10.1111/j.1365-294X.2012.05684.x

Ma, Z., Guo, W., Guo, X., Wang, X., and Kang, L. (2011). Modulation of behavioral phase changes of the migratory locust by the catecholamine metabolic pathway. Proc. Natl. Acad. Sci. U.S.A. 108, 3882-3887. doi: 10.1073/pnas.1015098108

Ma, Z., Guo, X., Lei, H., Li, T., Hao, S., and Kang, L. (2015). Octopamine and tyramine respectively regulate attractive and repulsive behavior in locust phase changes. Sci. Rep. 5:8036. doi: 10.1038/srep08036

Magor, J. I., Lecoq, M., and Hunter, D. M. (2008). Preventive control and Desert Locust plagues. Crop Protect. 27, 1527-1533. doi: 10.1016/j.cropro.2008.08.006

Maiga, I. H., Axelsen, J. A., Badji, K., and Kooyman, C. (2009). Simulation studies of Senegalese Grasshopper ecosystem interactions III: optimization of grasshopper control. Int. J. Pest Manag. 55, 113-120. doi: 10.1080/09670870802601092

Maiga, I. H., Lecoq, M., and Kooyman, C. (2008). Ecology and management of the Senegalese grasshopper Oedaleus senegalensis (Krauss 1877) (Orthoptera: Acrididae) in West Africa: review and prospects. Ann. Soc. Entomol. France 44, 271-288. doi: 10.1080/00379271.2008.10697563

Maiga, I. H., Lecoq, M., and Morand, S. (2010). Egg survival strategies of the Senegalese grasshopper during the dry season in the African Sahel. Int. J. Pest Manag. 56, 223-232. doi: 10.1080/09670870903464390

Maxwell-Darling, R. C. (1936). The outbreak centres of Schistocerca gregaria, Forsk., on the Red Sea coast of the Sudan. Bull. Entomol. Res. 27, 37-66. doi: 10.1017/S0007485300058107

Medina, H. E., Cease, A., and Trumper, E. (2017). The resurgence of the South American locust (Schistocerca cancellata). Metaleptea 37, 17-21.

Mignon, J. (2002). L'entomophagie : une question de culture? - Mignon Jacques. Tropicultura 20, 151-155.

Miller, G. A., and Simpson, S. J. (2010). 1582301. Isolation from a marching band increases haemocyte density in wild locusts (Chortoicetes terminifera). Ecol. Entomol. 35, 236-239. doi: 10.1111/j.1365-2311.2010.01180.x

Mohamed Shaluf, I. (2007). An overview on disasters. Disaster Prev. Manag. 16, 687-703. doi: $10.1108 / 09653560710837000$

Moussi, A., Abba, A., Harrat, A., and Petit, D. (2011). Desert acridian fauna (Orthoptera, Acridomorpha): comparison between steppic and oasian habitats in Algeria. Compt. Rendus Biol. 334, 158-167. doi: 10.1016/j.crvi.2010.12.001

Nevo, D. (1996). The desert locust, Schistocerca gregaria, and its control in the land of Israel and the Near East in antiquity, with some reflections on its appearance in Israel in modern times. Phytoparasitica 24, 7-32. doi: 10.1007/BF02981450
Oedekoven, M. A., and Joern, A. (2000). Plant quality and spider predation affects grasshoppers (Acrididae): food-quality-dependent compensatory mortality. Ecology 81, 66-77. doi: 10.1890/0012-9658(2000)081[0066:PQASPA]2.0.CO;2

Onsager, J. A. (2000). Suppression of grasshoppers in the Great Plains through grazing management. J. Range Manag. 592-602. doi: 10.2307/4003152

Onsager, J. A., and Olfert, O. (2000). "What tools have potential for grasshopper pest management?", in Grasshoppers and Grassland Health, eds J. Lockwood, A. Latchininsky, and M. G. Sergeev (New York, NY: Springer), 145-156. doi: 10.1007/978-94-011-4337-0_10

Osimani, A., Garofalo, C., Aquilanti, L., Milanović, V., Cardinali, F., Taccari, M., et al. (2017). Transferable antibiotic resistances in marketed edible grasshoppers (Locusta migratoria migratorioides). J. Food Sci. 82, 1184-1192. doi: $10.1111 / 1750-3841.13700$

Pasquier, R. (1934). Contributiona l'étude du Criquet marocain, Dociostaurus maroccanus Thunb., en Afrique mineure (lre note). Bull. Soc. Hist. Nat. Afr. Nord. 25, 167-200.

Pedgley, D. (1981). Desert Locust Forecasting Manual.. London: COPR.

Pener (1991). "Locust phase polymorphism and its endocrine relations," in Advances in Insect Physiology, ed P. D. Evans (London: Elsevier), 1-79. doi: 10.1016/S0065-2806(08)60091-0

Pener, M. P., and Simpson, S. J. (2009). "Locust phase polyphenism: an update," in Advances in Insect Physiology, eds S. J. Simpson and M. P. Pener (London: Academic Press), 1-272. doi: 10.1016/S0065-2806(08)36001-9

Phiriyangkul, P., Srinroch, C., Srisomsap, C., Chokchaichamnankit, D., and Punyarit, P. (2015). Effect of food thermal processing on allergenicity proteins in Bombay locust (Patanga succincta). Int. J. Food Eng. 1, 23-28. doi: 10.18178/ijfe.1.1.23-28

Piou, C., Lebourgeois, V., Benahi, A. S., Bonnal, V., Jaavar, M. H., Lecoq, M., et al. (2013). Coupling historical prospection data and a remotely-sensed vegetation index for the preventative control of Desert locusts. Basic Appl. Ecol. 14, 593-604. doi: 10.1016/j.baae.2013.08.007

Poot-Pech, M. A. (2016). "La langosta voladora Schistocerca piceifrons (Orthoptera: Acrididae): hacia un manejo sustentable. El Patrimonio, su Importancia y Conservación," in Conociendo el Patrimonio, Cuerpo Académico Patrimonio y Desarrollo Sustentable, Edito-rial TECCIS ed E. Fontes (San Francisco de Campeche), 58-66.

Poot-Pech, M. A., Ruiz-Sánchez, E., Ballina-Gómez, H. S., Gamboa-Angulo, M. M., and Reyes-Ramírez, A. (2016). Olfactory response and host plant feeding of the Central American Locust Schistocerca piceifrons piceifrons Walker to common plants in a gregarious zone. Neotrop. Entomol. 45, 382-388. doi: 10.1007/s13744-016-0385-y

Poot-Pech, M. A., Ruiz-Sánchez, E., Gamboa-Angulo, M., Ballina-Gómez, H. S., and Reyes-Ramírez, A. (2018). Population fluctuation of Schistocerca piceifrons piceifrons (Orthoptera: Acrididae) in the Yucatán Península and its relation with the environmental conditions. Rev. Biol. Trop. 66, 403-414. doi: $10.15517 /$ rbt.v66i1.29502

Popov, G. B. (1980). Studies on Oviposition, Egg Development and Mortality in Oedaleus senegalensis (Krauss), (Orthoptera, Acridoidea) in the Sahel. London: Centre for Overseas Pest Research, 33-48.

Popov, G. B., Duranton, J.-F., and Gigault, J. (1991). Etude Écologique des Biotopes du Criquet Pèlerin\# Schistocerca gregaria\#(Forskal, 1775) en Afrique Nord-Occidentale: Mise en Évidence et Description des Unités Territoriales Écologiquement Homogènes. CIRAD-PRIFAS.

Price, R. E., and Brown, H. D. (2000). "A century of locust control in South Africa," in Workshop on Research Priorities for Migrant Pests of Agriculture in Southern Africa (Chatham) 37-49.

Qin, Y., Li, Z., Zhao, L., Fowler, G., and Fang, Y. (2012). “The current and future potential geographical distribution of the Italian locust, Calliptamus italicus (Linnaeus)(Orthoptera: Acrididae) in China," in International Conference on Computer and Computing Technologies in Agriculture (Beijing: Springer), 290-298. doi: 10.1007/978-3-642-36137-1_35

Qing, Y. Q. L. Z. L., and Chunxian, Y. G. F. C. J. (2008). Feeding habits and economic threshold of Locusta migratoria tibetensis. Acta Phytophylac. Sin. 5.

Rankin, M. A., and Burchsted, J. C. A. (1992). The cost of migration in insects. Annu. Rev. Entomol. 37, 533-559. doi: 10.1146/annurev.en.37.010192. 002533

Raubenheimer, D., and Simpson, S. J. (1993). The geometry of compensatory feeding in the locust. Anim. Behav. 45, 953-964. doi: 10.1006/anbe.1993.1114 
Riley, J. R., and Reynolds, D. R. (1983). A long-range migration of grasshoppers observed in the Sahelian zone of Mali by two radars. J. Anim. Ecol. 167-183. doi: $10.2307 / 4594$

Ritchie, J. M. (1978). Melanism in Oedaleus senegalensis and other oedipodines (Orthoptera, Acrididae). J. Nat. Hist. 12, 153-162.

Ritchie, J. M. (1981). A Taxonomic Revision of the Genus Oedaleus Fieber (Orthoptera: Acrididae)[Including Crop Pests]. London: Bulletin of the British Museum. Natural History. Entomology.

Robinson, B. E., Li, P., and Hou, X. (2017). Institutional change in social-ecological systems: the evolution of grassland management in Inner Mongolia. Glob. Environ. Change 47, 64-75. doi: 10.1016/j.gloenvcha.2017.08.012

Robinson, M. D. (2001). Desert nitrogen cycles: fecal nitrogen from a population of the Sahelian Tree Locust in Oman. Sultan Qaboos Univ. J. Sci. 6, 33-38. doi: 10.24200/squjs.vol6iss1pp33-38

Roessingh, P., Bouaïchi, A., and Simpson, S. J. (1998). Effects of sensory stimuli on the behavioural phase state of the desert locust, Schistocerca gregaria. J. Insect Physiol. 44, 883-893. doi: 10.1016/S0022-1910(98)00070-5

Roffey, J. (1979). Locusts and Grasshoppers of Economic Importance in Thailand. London: Locusts and grasshoppers of economic importance in Thailand.

Roffey, J., and Magor, J. I. (2003). Desert Locust Popualation Dynamics Parameters. Technical Series-Desert Locust Field Reserch Stations (FAO).

Roffey, J., and Popov, G. (1968). Environmental and behavioural processes in a desert locust outbreak. Nature 219, 446. doi: 10.1038/219446a0

Rogers, S. M., Cullen, D. A., Anstey, M. L., Burrows, M., Despland, E., Dodgson, T., et al. (2014). Rapid behavioural gregarization in the desert locust, Schistocerca gregaria entails synchronous changes in both activity and attraction to conspecifics. J. Insect Physiol. 65, 9-26. doi: 10.1016/j.jinsphys.2014.04.004

Rogers, S. M., Matheson, T., Despland, E., Dodgson, T., Burrows, M., and Simpson, S. J. (2003). Mechanosensory-induced behavioural gregarization in the desert locust Schistocerca gregaria. J. Exp. Biol. 206, 3991-4002. doi: 10.1242/jeb.00648

Schmitz, O. J. (2008). Effects of predator hunting mode on grassland ecosystem function. Science 319, 952-954. doi: 10.1126/science,.1152355

SENASICA-D GSV. (2016). Langosta Centroamericana [Schistocerca piceifrons piceifrons (Walker, 1870).

Sergeev, M. G., and Van'kova, I. A. (2008). Dynamics of the Italian locust Calliptamus italicus L. population in the southeast of the West Siberian Plain. Contempor. Probl. Ecol. 1, 204-209. doi: 10.1134/S19954255080 20057

Serville, M. A. (1838). Histoire Naturelle des Insectes Orthoptères (dans les Suites à Buffon). Paris: Roret.

Shen, K., Wang, H.-J., Shao, L., Xiao, K., Shu, J.-P., Xu, T.-S., et al. (2009). Mudpuddling in the yellow-spined bamboo locust, Ceracris kiangsu (Oedipodidae: Orthoptera): does it detect and prefer salts or nitrogenous compounds from human urine? J. Insect Physiol. 55, 78-84. doi: 10.1016/j.jinsphys.2008. 10.011

Simpson, S. J., and Raubenheimer, D. (2000). The hungry locust. Adv. Study Behav. 29, 1-44. doi: 10.1016/S0065-3454(08)60102-3

Simpson, S. J., Raubenheimer, D., Behmer, S. T., Whitworth, A., and Wright, G. A. (2002). A comparison of nutritional regulation in solitarious- and gregarious-phase nymphs of the desert locust Schistocerca gregaria. J. Exp. Biol. 205, 121-129.

Skaf, R. M. (1972). "Problem of introducing modern methods of chemical control of locusts in the developing countries," in International Study Conference on the Current and Future Problems of Acridology, London, 1970. Proceedings.

Sokol-Hessner, L., and Schmitz, O. J. (2002). Aggregate effects of multiple predator species on a shared prey. Ecology 83, 2367-2372. doi: 10.1890/00129658(2002)083[2367:AEOMPS]2.0.CO;2

Song, H. (2011). Density-dependent phase polyphenism in nonmodel locusts: a minireview. Psyche. 2011:741769. doi: 10.1155/2011/741769

Song, H., Mariño-Pérez, R., Woller, D. A., and Cigliano, M. M. (2018). Evolution, diversification, and biogeography of grasshoppers (Orthoptera: Acrididae). Insect Syst. Divers 2, 1-25. doi: 10.1093/isd/ixy008

Spalinger, L. C., Haynes, A. G., Schuetz, M., and Risch, A. C. (2012). Impact of wild ungulate grazing on Orthoptera abundance and diversity in subalpine grasslands. Insect Conserv. Diver. 5, 444-452. doi: 10.1111/j.1752-4598.2011.00180.x

Stanley, M. (2018). Locusts Swarm in the Pilbara and Kimberley, Costing Farmers Thousands. ABC Rural. Available online at: https://www.abc.net.au/ news/rural/2018-04-02/yellow- winged-locust- plague- swarms-northern-wastations/9603136 (accessed February 28, 2019).

Steedman, A. (1990). Locust handbook. Chatham: Natural Resources Institute.

Stige, L. C., Chan, K.-S., Zhang, Z., Frank, D., and Stenseth, N. C. (2007). Thousand-year-long Chinese time series reveals climatic forcing of decadal locust dynamics. Proc. Natl. Acad. Sci. U.S.A. 104, 16188-16193. doi: $10.1073 /$ pnas.0706813104

Stolyarov, M. V. (2000). Strategy and tactics of gregarious locust control. Zashchita Karantin Rastenii 10, 17-19.

Stoops, J., Crauwels, S., Waud, M., Claes, J., Lievens, B., and Van Campenhout, L. (2016). Microbial community assessment of mealworm larvae (Tenebrio molitor) and grasshoppers (Locusta migratoria migratorioides) sold for human consumption. Food Microbiol. 53, 122-127. doi: 10.1016/j.fm.2015.09.010

Sword, G. A. (1999). Density-dependent warning coloration. Nature 397, 217. doi: $10.1038 / 16609$

Sword, G. A. (2001). Tasty on the outside, but toxic in the middle: grasshopper regurgitation and host plant-mediated toxicity to a vertebrate predator. Oecologia 128, 416-421. doi: 10.1007/s004420100666

Sword, G. A. (2002). A role for phenotypic plasticity in the evolution of aposematism. Proc. R. Soc. Lond. B Biol. Sci. 269, 1639-1644. doi: $10.1098 / \mathrm{rspb} .2002 .2060$

Sword, G. A., Simpson, S. J., El Hadi, O. T. M., and Wilps, H. (2000). Densitydependent aposematism in the desert locust. Proc. R. Soc. Lond. Ser. B Biol. Sci. 267, 63-68. doi: 10.1098/rspb.2000.0967

Symmons, P. (2009). A critique of "Preventive control and desert locust plagues." Crop Protect. 28, 905-907. doi: 10.1016/j.cropro.2009.04.012

Symmons, P. M. (1984). Control of the Australian plague locust, Chortoicetes terminifera (Walker). Crop Protect. 3, 479-490. doi: 10.1016/0261-2194(84)90029-2

Symmons, P. M., and Cressman, K. (2001). Desert Locust Guidelines: Biology and Behavior. Rome: Food and Agriculture Organization of the United Nations.

Tanaka, S., and Zhu, D.-H. (2005). Outbreaks of the migratory locust Locusta migratoria (Orthoptera: Acrididae) and control in China. Appl. Entomol. Zool. 40, 257-263. doi: 10.1303/aez.2005.257

Thindwa, H. P. (1999). Red Locust Population Monitoring and Control in Malawi, 1988-1998. Int. J. Trop. Insect Sci. 19, 351-354. doi: 10.1017/S174275840001897X

Tian, H., Stige, L. C., Cazelles, B., Kausrud, K. L., Svarverud, R., Stenseth, N. C., et al. (2011). Reconstruction of a 1,910-y-long locust series reveals consistent associations with climate fluctuations in China. Proc. Natl. Acad. Sci. U.S.A. 108, 14521-14526. doi: 10.1073/pnas.11001 89108

Tingle, C. C. D., Rother, J. A., Dewhurst, C. F., Lauer, S., and King, W. J. (2003) "Fipronil: environmental fate, ecotoxicology, and human health concerns," in Reviews of Environmental Contamination and Toxicology: Continuation of Residue Reviews, ed. G. W. Ware (New York, NY: Springer New York), 1-66. doi: 10.1007/978-1-4899-7283-5_1

Todd, M. C., Washington, R., Cheke, R. A., and Kniveton, D. (2002). Brown locust outbreaks and climate variability in southern Africa. J. Appl. Ecol. 39, 31-42. doi: 10.1046/j.1365-2664.2002.00691.x

Toleubayev, K., Jansen, K., and van Huis, A. (2007). Locust control in transition: the loss and reinvention of collective action in post-soviet Kazakhstan. Ecol. Soc. 12, 38. doi: 10.5751/ES-02229-120238

Toure, M., Ndiaye, M., and Diongue, A. (2013). Effect of cultural techniques: Rotation and fallow on the distribution of Oedaleus senegalensis (Krauss, 1877)(Orthoptera: Acrididae) in Senegal. Afr. J. Agric. Res. 8, 5634-5638.

Urech, R. (2003). Influence of spreading woody plants and surface cover on the distribution of calliptamus italicus and Oedipoda caerulescens (Saltatoria, Caelifera) in a steppe habitat (Diplomarbeit). Universität Bern, Bern, Switzerland.

Uvarov, B. (1966). Grasshoppers and Locusts: A Handbook of General Acridology. 1. Anatomy, Physiology, Development, Phase Polymorphism, Introduction to Taxonomy. Cambridge: University Press.

Uvarov, B. (1977). Grasshoppers and Locusts. A Handbook of General Acridology Vol. 2. Behaviour, Ecology, Biogeography, Population Dynamics. Cambridge: Centre for Overseas Pest Research.

Uvarov, B. P. (1936). The oriental migratory locust (Locusta migratoria manilensis, Meyen 1835). Bull. Entomol. Res. 27, 91-104. doi: 10.1017/S0007485300058144 
Van Der Werf, W., Woldewahid, G., Van Huis, A., Butrous, M., and Sykora, K. (2005). Plant communities can predict the distribution of solitarious desert locust Schistocerca gregaria. J. Appl. Ecol. 42, 989-997. doi: 10.1111/j.1365-2664.2005.01073.x

Van Huis, A., Cressman, K., and Magor, J. I. (2007). Preventing desert locust plagues: optimizing management interventions. Entomol. Exp. Applic. 122, 191-214. doi: 10.1111/j.1570-7458.2006.00517.x

Van Huis, A., Woldewahid, G., Toleubayev, K., and Van Der Werf, W. (2008). Relationships between food quality and fitness in the desert locust, Schistocerca gregaria, and its distribution over habitats on the Red Sea coastal plain of Sudan. Entomol. Exp. Applic. 127, 144-156. doi: 10.1111/j.1570-7458.2008. 00682.x

Veran, S., Simpson, S. J., Sword, G. A., Deveson, E., Piry, S., Hines, J. E., et al. (2015). Modeling spatiotemporal dynamics of outbreaking species: influence of environment and migration in a locust. Ecology 96, 737-748. doi: 10.1890/14-0183.1

Vesey-Fitzgekald, D. F. (1955). "The vegetation of the outbreak areas of the red locust (Nomadacris septemfasciata Sers.) in Tanganyika and Northern Rhodesia. The Vegetation of the Outbreak Areas of the Red Locust (Nomadacris septemfasciata Sers)," in Tanganyika and Northern Rhodesia. Available online at: https://www.cabdirect.org/cabdirect/abstract/ 19560500242 (accessed March 12, 2018). doi: 10.1080/00306525.1955. 9633036

Vinokurov, G. M., and Rubtzov, I. A. (1930). Studies on the Ecology of Grasshoppers in the Irkutsk Region. Irkutsk: Studies on the Ecology of Grasshoppers in the Irkutsk Region.

Walker, P. R., Hill, L., and Bailey, E. (1970). Feeding activity, respiration, and lipid and carbohydrate content of the male desert locust during adult development. J. Insect Physiol. 16, 1001-1015. doi: 10.1016/0022-1910(70)90229-5

Waloff, Z., and Green, S. M. (1976). Some temporal characteristics of desert locust plagues with a statistical analysis. Antilocust Mem. Minist Overseas Dev. Antilocust. Res. Cent. Lond. 1976:36.

Waloff, Z., and Pedgley, D. E. (1986). Comparative biogeography and biology of the South American locust, Schistocerca cancellata (Serville), and the South African desert locust, S. gregaria flaviventris (Burmeister)(Orthoptera: Acrididae): a review. Bull. Entomol. Res. 76, 1-20. doi: 10.1017/S00074853000 15236

Wang, D. C. (2004). The study on the breakout and disserving of grasshopper in Sunitezuo Banner, Inner Mongolia. Inner Mongolia Pratacult. 16, 14-15.

Wang, H., Shao, L., Sju, J., Shen, K., Xia, K., Li, G., et al. (2010). Analysis of some human urine-borne phagostimulants to the yellow-spined bamboo locust, Ceracris kiangsu. J. Nanjing Agric. Univ. 2.

Watts, J. G., Huddleston, E. W., and Owens, J. C. (1982). Rangeland entomology. Annu. Rev. Entomol. 27, 283-311. doi: 10.1146/annurev.en.27.010182.001435

Weis-Fogh, T. (1952). Fat combustion and metabolic rate of flying locusts (Schistocerca gregaria Forskaal). Phil. Trans. R. Soc. Lond. B 237, 1-36. doi: 10.1098/rstb.1952.0011

White, T. C. (2012). The Inadequate Environment: Nitrogen and the Abundance of Animals. Berlin: Springer Science and Business Media.

Wiens, J. A. (1973). Pattern and process in grassland bird communities. Ecol. Monogr. 43, 237-270. doi: 10.2307/19 42196

Wilps, H., and Diop, B. (1997). "Field investigations on Schistocerca gregaria (Forskaal) adults, hoppers and hopper bands," in New Strategies in Locust Control, eds S. Krall, R. Peveling, and D. Ba Diallo (Basel: Springer), 117-128. doi: 10.1007/978-3-0348-9202-5_16
Wilps, H., Levchenko, V., and Vernigor, A. (2002). Field trials with Imidacloprid (Confidor) on the Italian locust Calliptamus italicus in Kazakhstan. J. Appl. Entomol. 126, 436-443. doi: 10.1046/j.1439-0418.2002.00676.x

Woodman, J. D. (2017). Effects of substrate salinity on oviposition, embryonic development and survival in the Australian plague locust, Chortoicetes terminifera (Walker). J. Insect Physiol. 96, 9-13. doi: 10.1016/j.jinsphys.2016.10.001

Word, M. L., Hall, S. J., Robinson, B., Manneh, B., Beye, A., and Cease, A. J. (2019). Soil-targeted interventions could alleviate locust and grasshopper pest pressure in West Africa. Sci. Total Environ. 663, 632-643. doi: 10.1016/j.scitotenv.2019.01.313

Wright, D. E. (1983). The Origin and Development of Major Plagues of Chortoicetes terminifera. Oxford: Walker.

Wright, D. E., and Symmons, P. M. (1987). The development and control of the 1984 plague of the Australian plague locust, Chortoicetes terminifera (Walker). Crop Protect. 6, 13-19. doi: 10.1016/0261-2194(87)90022-6

Wu, T., Hao, S., Sun, O. J., and Kang, L. (2012). Specificity responses of grasshoppers in temperate grasslands to diel asymmetric warming. PLoS ONE 7:e41764. doi: 10.1371/journal.pone.0041764

Xinghui, Q., and Hongchang, L. (1997). Effect of livestock exclusion on abundance of grasshoppers on Aneurolepidium chinense and Stipa grandis steppes. Chin. J. Appl. Ecol. 4:013.

Xu, H., Su, H., Su, B., Han, X., Biswas, D. K., and Li, Y. (2014). Restoring the degraded grassland and improving sustainability of grassland ecosystem through chicken farming: a case study in northern China. Agric. Ecosyst. Environ. 186, 115-123. doi: 10.1016/j.agee.2014.02.001

Yang, L., and Wang, J. (2004). Meteorological factors on grasshopper bloom in Hami Area. Chin. J. Ecol. 6:009.

Yu, H.-P., Shen, K., Wang, Z.-T., Mu, L.-L., and Li, G.-Q. (2011a). Population control of the yellow-spined bamboo locust, Ceracris kiangsu, using urineborne chemical baits in bamboo forest. Entomol. Exp. Applic. 138, 71-76. doi: 10.1111/j.1570-7458.2010.01076.x

Yu, H.-P., Wang, Z.-T., Xiao, K., Shao, L., and Li, G.-Q. (2011b). The presence of conspecific decoys enhances the attractiveness of an $\mathrm{NaCl}$ resource to the yellow-spined locust, Ceracris kiangsu. Journal of insect science 11, 45. doi: 10.1673/031.011.0145

Zhang, L., and Hunter, D. (2017). Management of locusts and grasshoppers in China. Journal of Orthoptera Research 26, 155. doi: 10.3897/jor.26.20119

Zhang, L., Lecoq, M., Latchininsky, A., and Hunter, D. (2019). Locust and Grasshopper Management. Annual Review of Entomology 64, 15-34. doi: 10.1146/annurev-ento-011118-112500

Zhang, Z., Elser, J. J., Cease, A. J., Zhang, X., and Yu, Q. (2014). Grasshoppers Regulate N: P Stoichiometric Homeostasis by Changing Phosphorus Contents in. doi: 10.1371/journal.pone.0103697

Conflict of Interest Statement: The authors declare that the research was conducted in the absence of any commercial or financial relationships that could be construed as a potential conflict of interest.

Copyright (c) 2019 Le Gall, Overson and Cease. This is an open-access article distributed under the terms of the Creative Commons Attribution License (CC BY). The use, distribution or reproduction in other forums is permitted, provided the original author(s) and the copyright owner(s) are credited and that the original publication in this journal is cited, in accordance with accepted academic practice. No use, distribution or reproduction is permitted which does not comply with these terms. 